\title{
Faire mieux que la nature? The History of Eel Restocking in Europe
}

\author{
WILLEM DEKKER
}

Swedish University of Agricultural Sciences

Department of Aquatic Resources, Institute for Freshwater Research

Stångholmsvägen 2, SE-17893 Drottningholm, Sweden.

Email: Willem.Dekker@slu.se

\section{LAURENT BEAULATON}

Onema, pôle gest'aqua / INRA, U3E (1036), pôle gest'aqua

65 rue de Saint Brieuc

35042 Rennes Cedex, France.

Email: Laurent.Beaulaton@onema.fr

\begin{abstract}
Young eel, recruiting from the ocean towards Europe, are most abundant along the Atlantic coast of France. Since 1840, attempts have been made to redistribute them from the areas of highest abundance to other countries and farther inland. This 'restocking' has been troubled by technical constraints (e.g. mode of transport and maximum distance eel can be shipped alive), wars (e.g. the Franco-Prussian War and World Wars One and Two) and, in recent decades, by shortage of supply due to the general decline of the eel stock all across Europe. Though objectives and procedures have changed considerably over the years, the recurring aim has been to increase production and, in that way, to 'faire mieux que la nature'. We document the historical development of these efforts from their inception, and contrast the achievements to the objectives. Except for the 1952-1990 period in Eastern Europe, restocking has probably added only slightly to the natural production. As successful as restocking might have been locally, it has not markedly changed the overall trends and distribution patterns or halted the general decline of the stock and fishery. Poor post-evaluation, frequent technical innovation and a constant renewal of the countries and people involved have kept the promise of a better future alive for 175 years.
\end{abstract}

\section{KEYWORDS}

Eel, Anguilla, glass eel, bootlace, restocking, stocking, fishery, technical development, natural resources, international cooperation, development and protection, enhancement and recovery. 


\section{INTRODUCTION}

Just one single fish species is exploited in all countries of Europe, and Europe is currently struggling to develop a common policy for protecting this shared resource - that fish is the European eel, Anguilla anguilla (L.). Over the last two centuries, the peculiar biology of the eel, technical developments and political constraints have resulted in the alternation of cooperation and animosity between European countries regarding the development of their eel fisheries. In this article, we discuss one aspect of this situation: the artificial redistribution of natural-born young eel over the whole continent, a practice known as restocking. ${ }^{1}$

\section{Enhancing fish stocks}

In early medieval Europe, increasing human populations negatively affected stocks of wild fish in rivers and lakes. To compensate for the decline in natural production, fishponds were created, constituting controlled production environments operating at a high fish density. Often, fishponds physically replaced wild habitats (e.g. ponds were created by blocking rivers), and new species better fit for pond culture, such as carp, were introduced to supplement the native fauna. As successful as pond culture was, its production was limited, and fresh fish was predominantly reserved for the nobility and clergy. Little is known about the relative importance of the fisheries continuing in the deteriorating wild habitats. It is only in the 1700 s that we find renewed interest in wild fish stocks and only in the 1800s that actions were taken to restore and increase those stocks. Rather than increasing the already high productivity of relatively small fishponds, efforts were made to increase the low productivity of wild habitats, exploiting their vast surface area to increase overall production. In the mid-1800s, attention was concentrated on 'seeding the waters' by releasing masses of young fish into degraded habitats. The apparent assumption was that habitat degradation mainly affected the reproductive phase and that stocked juveniles could still find satisfactory resources for growth and survival. In the actual or supposed absence of reproduction, such 'seeding' had to be repeated every year in sufficient numbers, creating immense logistical problems. Technical developments in the 1800s, such as hatcheries and improved transportation, eventually culminated in the mass production and distribution of eggs and young fish, released into the wild. ${ }^{2}$

1. The concept of restocking appears to be vaguely defined, at least partly due to its historical embedding in the development of artificial reproduction and fish culture. We will derive a definition of restocking after we have presented the first developments, and discuss the vague boundary between restocking and fish culture later.

2. Hoffmann (1995) provides a historical overview of the relationships between human population growth, agriculture, aquatic habitats, and fish culture. Kinsey (2006) discusses the development of fish culture in the 1800s. Examples of descriptive studies of wild habitats, 
The eel is a strange animal, however, not a normal fish by general standards. When fish culture took off in the mid-1800s, it was expected that eel could be reproduced artificially, like any other fish. Eel constituting a major share of inland fish catches across Europe, it was one of the first species to concentrate $\mathrm{on}^{3}$. Its reproduction, however, turned out to be much more complex than anticipated; artificial reproduction is still not feasible, even today. A parallel effort to redistribute natural-born young eel ('glass eel') was attempted instead, transporting them from areas of highest abundance (primarily French river mouths) to under-populated waters all over Europe. This redistribution has become commonly known as 'stocking' or 'restocking' (i.e. repeuplement, Aussetzung, Besatz, uitzet, utsättning, udscetning, ripopolamenti, zarybianiu and посадочныій). Though this restocking was organised within the broader context of fish culture, the logistical problems of eel restocking were much greater, due to the dependence on natural-born recruits.

\section{Eel biology and related terminology}

The European eel is found and exploited in fresh, brackish and coastal waters throughout most of Europe (though in the Black Sea area, natural occurrence is doubtful) and along the Mediterranean coasts of Africa and Asia. This wide distribution area, however, is effectively fragmented among thousands of river catchments, with little or no natural interaction between them. Genetic analysis has demonstrated that all eels in Europe belong to one species, even one and the same population. Although the life cycle is incompletely understood, reproduction is thought to take place somewhere in the Atlantic Ocean, most likely in the Sargasso Sea, more than 5,000 km west of the continent, where the smallest larvae are found. ${ }^{4}$

fish, and fisheries include those of Marsilius (1726) and Duhamel de Monceau (1769); we know of no studies quantifying the volume produced by medieval wild fisheries. Note that shellfish culture in coastal waters often did/does the complement of stocking, providing artificial growing habitat for naturally recruiting youngsters, in contrast to stocking artificial recruits in natural growing habitats.

3. Initially, the artificial reproduction of many different fish species was tried, such as perch and tench, and it was generally expected that the same techniques could also be applied to 'salmon and eel, etcetera' (Anonymous 1852)

Catch statistics for inland fisheries are notoriously incomplete. FAO (2014) started collecting statistics after World War Two, but the incompleteness of the available information is manifest (Dekker 2003b). In the 1950s, eel was the most abundant identified species in the inland catches of Europe (excluding Russia), constituting 5 per cent of the total catch volume, approximately 25 per cent of catch values (Dekker and Beaulaton, 2015). Earlier information does not allow quantification, but the eel was probably even more abundant before.

4. The wide distribution is analysed by Dekker (2003a), the fragmentation by Dekker (2000). Schmidt (1922) identified the Sargasso Sea as the spawning place, but Tucker (1959) criticised that claim, noting that reproducing animals had never actually been observed. For the genetics of the stock, see, for example, Dannewitz et al. (2005). 
The Bay of Biscay area receives approximately ninety per cent of all glass eel recruitment; yellow and silver eel are more evenly spread over the wide distribution area. The eel can tolerate a wide range of environmental conditions (e.g. temperature, salinity, depth, trophic status and flow rate) and can survive considerable periods out of the water. Eels grow and mature in two to fifty years (average age ten, maximum age $>85$, max. length $133 \mathrm{~cm}$ ), but females become about twice the age and size of males. No-one has ever observed spawning adults or eggs in the wild. ${ }^{5}$

Different life stages of the eel have specific names: the transparent youngsters coming from the Atlantic Ocean towards the European coasts are called glass eel; in the growing phase, they are known as yellow eel (though they are brownish/greenish); and when finally starting maturation and returning to the ocean, they are called silver eel (silvery belly, nearly black dorsal). The young eel migrating into our rivers are often called elvers, but whether that term includes only the youngest pigmented yellow eel or also the stilltransparent glass eel stage depends on the time, location and speaker; we avoid this ambiguous terminology. Finally, young yellow eel of intermediate size are sometimes called bootlace eel; bootlaces are ten to thirty centimetres long, but the definition varies with time and between regions. Within the context of restocking, the mass of glass eel being used is often indicated by the French word 'montée', all across Europe. Most restocking concerns true glass eel, but many historical sources do not exactly specify their material. Finally, we prefer the term 'restocking' to 'stocking', because the young eel resources are generally redistributed to habitats where they appeared before, and released there - rather than used to seed, to start a new stock.

Related, but truly different, Anguilla species occur in North America, eastern Asia, Australia, New Zealand and many tropical areas. The stories of these temperate eel species display strong parallels. Scientific as well as practitioner knowledge has been exchanged between the continents, and trade flows have led to interactions among stakeholders. In this article, we restrict the discussion to the European eel in Europe.

5. Despite more than two millennia of research, starting with Aristotle (ca. 350 bc), our knowledge of eel biology is far from complete, the most prominent mystery being the yetunobserved reproduction, assumed to occur in the far-out Sargasso Sea, south of Bermuda. After decades of research, artificial reproduction is still not practically feasible (Okamura et al. 2014).

Aristotle's work on the eel, described in Historia Animalium (Peck 1970), was likely the first-ever true experiment on fish. He describes how an isolated pool was scraped out, to find new eels after rain had replenished the pool. In his view, this proved the spontaneous generation of eels from the mud. Scraping out a muddy pool was far more experimental than Aristotle's usual observational analyses. 


\section{Stock status and protection}

In recent decades, the eel population has reached a very poor state: fishing yield has gradually declined to approximately ten per cent of the quantity caught just half a century ago (Figure 1); additionally, the recruitment of young eel from the ocean has fallen since 1980 to between one and ten per cent of former levels (Figure 2). Indoor rearing of wild-caught young eel (commonly known by the unspecific name of 'aquaculture') has partly compensated for the declining fishing yield for some time - but ultimately, the ongoing decline of the natural stock has set a limit on the supply of seed for aquaculture too. ${ }^{6}$

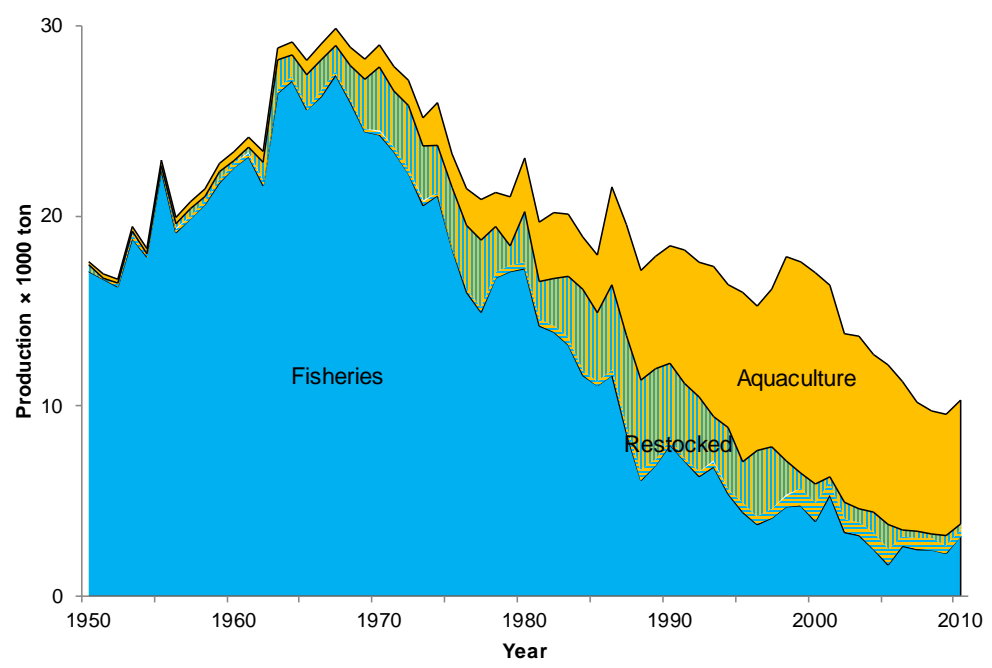

Figure 1. Time series of eel production, comprising fishing yield and aquaculture. For the fishing yield, the hatched part is what we attribute to restocking (vertical hatching: from glass eel; horizontal hatching: from bootlace). Data after 2010 are not yet completely available. Data are from Dekker (2003b, updated) and ICES-WGEEL (2013); yield based on restocking has been reconstructed from the material presented here and is separated from the total fishing yield.

Though we understand the causes of the downward trends in the eel population only poorly, it is clear that humans interact with the stock dynamics in many ways, via habitat destruction, pollution, fisheries and barriers to migration, as well as the capture and redistribution of young recruits. In 2007, the European Union (EU) adopted a recovery plan, aiming to return the population to its historical abundance. This 'Eel Regulation' obliges Member States to develop national Eel Management Plans. The aim of these Plans is to

6. Dekker (2004a) analysed the eel stock dynamics in recent decades; ICES-WGEEL (2015) provides the most recent update. 


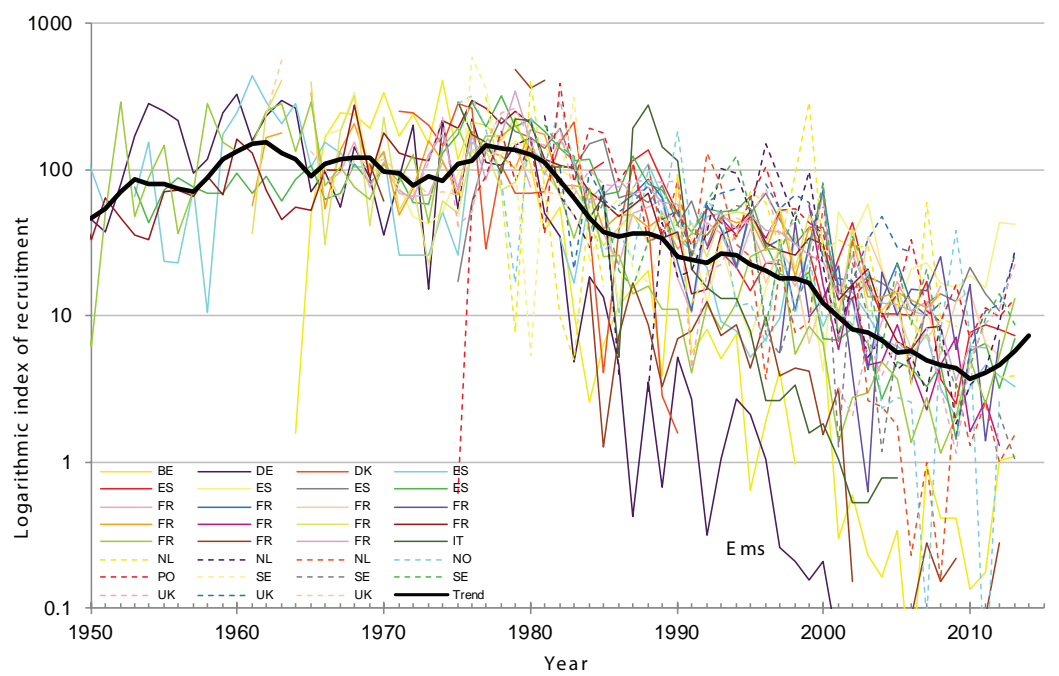

Figure 2. Time series of recruitment to European inland waters. This graph shows individual data series from all over Europe (countries identified by their internet codes), expressed as indices (i.e. relative units). Several countries provide multiple, independent data series. Data from ICES-WGEEL (2013). Note the logarithmic vertical scale in this graph, in contrast to the normal scale of Figure 1.

restore national stocks to sustainable levels, to their historical abundance, and restocking is one tool for accomplishing this. ${ }^{7}$

\section{Objectives and outlook}

To our knowledge, the historical development of eel culture and restocking in Europe has not been analysed before, and very few information sources have been disclosed, either at a regional or at the international level. In order to improve our knowledge of the historical stock and to assess the effect of past restockings, we collect information on eel restocking from all over Europe covering the last two centuries, describe the scientific and technical progress that enabled the developments and investigate the historical context.

Our motivation for this study originates in the assessment of the population dynamics of the stock: quantification of the historical impact of restocking on population and yield will improve our notion of the natural population that the European recovery plan aims to restore and of the potential of restocking as a stock enhancement measure. The conventional view in eel research is that restocking began in the early 1900s, centred in Germany. Studying the

7. Anonymous (2007) describes the Eel Regulation itself; Dekker (2008) described the process leading towards adoption. 
historical details, however, we found that to be incorrect, both in time and in space. The origin of eel restocking is embedded in the nascence of aquaculture in France in the mid-1800s. Though eel restocking was the primordial, as well as the most anomalous, case in that aquacultural revolution, it has remained fully unexposed, in the literature on environmental history as well as on eel biology and fisheries. We rectify that, reporting here from the original information sources for the first time.

Noting that restocking programmes are still carried on today, and that scientific and political debates continue, we describe the historical development up to the present, but we do not evaluate current actions in this article, contributing to that effort via other routes.

The structure of this paper is as follows. First, we describe the historical development of restocking, at different times, in different countries, and more or less in chronological order, focusing on technological development, logistics, and quantification of the transports over time. We then present a thematic assessment, evaluating whether the historical programmes have achieved their objectives, what has hampered them, and what has kept them going. Finally, we return to a broader setting, discussing the role eel restocking played in the development of general aquaculture - and vice versa - and relating today's societal debates on the protection of the eel to their historical context. ${ }^{8}$

8. The information presented here is based on the scientific literature, governmental publications (e.g. annual progress reports), and personal communications with colleagues working in various countries (especially members of the EIFAAC/ICES/GFCM Eel Working Group). For France, we have analysed all rapports/délibérations published before 1940 by the Conseils Généraux of all départements, and the Bulletins des Sociétés (Impériales) Zoologiques d'Acclimatation between 1854 and 1890 (available at http://gallica.bnf.fr). For Germany, we analysed the Allgemeine Fischerei-Zeitung (earlier known as Bayerischen FischereiZeitung) between 1876 and 1940; the Circulare des Deutschen Fischerei-Vereins between 1880 and 1892; and the Fischerei Zeitung between 1889 and 1940. For other countries, we did not find systematic data sources, so historical trends were compiled from recent reports and personal communications. More detailed data sources are specified in the text. Though we provide quantitative analyses of the information and have cross-checked our results with contemporary sources, we cannot claim to have covered all periods in all countries. We will consider the relevance of the available material where needed.

In calculating geographical distances between sources and destinations, we compare transport by road, train, aeroplane, and even horse cart or foot along unknown routes. We standardise comparisons by calculating great-circle distances, i.e. as the crow flies, which underestimates the true distances, but systematically so.

Throughout this article, we apply a standard conversion rate from glass eel to silver eel: $1 \mathrm{~kg}$ of glass eel consists of just over 3,000 individuals, approximately $10 \%$ of which survive to the silver eel stage and/or a harvestable size of $0.3 \mathrm{~kg}$ each; hence, $1 \mathrm{~kg}$ of glass eel produces about $100 \mathrm{~kg}$ of harvestable silver eel.

We express all historical prices in their original monetary units, and convert them to inflation-corrected $€$ 's (2000 base year). 


\section{THE HISTORY OF EEL RESTOCKING IN EUROPE}

The timeline of eel restocking consists of seven distinct episodes, some of which overlap in time. We discuss the early development of restocking techniques (1840-1880), the scaling-up towards a national programme in France (1879-1890), the programme to establish an eel stock in the River Danube (1881-1897), the German programme of importing glass eel from England (1908-1940), the heyday of restocking after World War Two (1945-2000), aquaculture gradually branching off from outdoor restocking (1980-present) and recently renewed interest in restocking as a protection measure (2009-present).

\section{Early developments, 1840-1880}

The first person ever to discuss the concept of restocking was Louis Riffardeau Baron de Rivière (1817-1890). He was the mayor of St Gilles, near the Camargue in southern France, where he owned extensive properties, but he also had land and a castle in Vernais, Cher, in central France. His involvements in land reclamation (in the Camargue) and agricultural development (in Cher) had made him aware of the value of water resources for agriculture, and of the underdeveloped exploitation of the aquatic resources themselves. He had noted the great abundance of (young) eel in the Camargue, and probably noted the lower abundance around Cher. In a lecture at the Societé Royale et Centrale d'Agriculture in Paris on 1 July 1840 (Rivière 1841), he discussed opportunities for improving aquatic resource exploitation. Following a lengthy description of the biology of eel (including four species of freshwater eel in France) and discussion of the likelihood of ovovivipary versus vivipary, he focused on practical opportunities: 'So ... could we not take steps to ensure that the distribution of these colonies [of glass eel], which come spontaneously to provide our needs, is made in proportion to the lakes and rivers to populate? Could we not send batches, if I may say so, wherever it may be possible to raise them, in particular where they cannot come themselves in sufficient quantity?' That same year, 3,500 glass eel (about $1 \mathrm{~kg}$ ) were transported from Abbeville to the peat digging canals in l'Aisne - a distance of just over 100 $\mathrm{km}$ - yielding 2,500 kg of 'belles anguilles' only five years later. Millet (1870) attributes the idea for the 1840 restocking in l'Aisne to de Rivière's lecture (1 July 1840), though the restocking must have happened the spring before the lecture was given. ${ }^{9}$

9. Millet (1870) reported that the 3,500 glass eels produced 2,500 kg of 'belles anguilles', which is an improbably high yield. A modern ballpark estimate would be some $100 \mathrm{~kg}$, possibly up to $1,000 \mathrm{~kg}$, but certainly not in the oligotrophic waters Millet was referring to. Was Millet deliberately exaggerating, to support the developing restocking programme? Unless they affect our results, we will not discuss further improbabilities. 
Over the millennia before Baron de Rivière's lecture, we find many reports of eel (and other fish) being held in tanks and ponds - in ancient Egypt, Greece, and Rome, and even as far from the sea as Vienna on the River Danube - and these must obviously have been brought in by the pond owners. Though some escaped, those eels were meant to be held in captivity, an approach differing fundamentally from Baron de Rivière's intention to supplement the natural stock, to exploit natural habitats. We consider a high number of imported young fish deliberately released into the wild as the defining characteristic of restocking, distinguishing it from deliberate or accidental introductions (in low numbers), pond culture (involving local reproduction) or local fish production enhancements (no or short-distance transport). We therefore consider Baron de Rivière to be the architect of modern eel restocking - even the architect of fish stocking in general - though his attempts with other fish had clearly failed ('Fish are difficult to transport alive [, but one can transport] eel without [their] appearing to suffer'). ${ }^{10}$

Little progress was made in the decade after Baron de Rivière's lecture, but in 1850, a more comprehensive programme to 'seed the waters' was proposed. The key to this development was the discovery and exploitation of artificial fish reproduction, especially of salmonids, in great numbers. Though artificial reproduction for the eel was not ruled out completely, its natural reproduction was known to be poorly understood, so restocking wild-caught glass eel was advocated instead. France, at the time, was a hotbed of fish culture activity. Over just a few years, a 'piscifactoire' [literally: fish factory - a hatchery] was set up in Huningue, just north of Basel along the river Rhine, where Victor Coste (1807-1873) was appointed director; young salmonids were being produced and transported all over France and the rest of the world; a transport procedure for glass eel was developed, using aerated wooden boxes filled with

On the abundance of eel in Cher: Dubois (1903) describes the eel as common in all waters, including in Cher. Almost no historical source allows full quantification, but abundance in the 1800s likely exceeded any levels observed recently, in Cher and certainly in the Camargue.

Baron de Rivière (1817-1890) was a member of the Societé Royale et Centrale d'Agriculture, as were Victor Coste (1807-1873), Charles Auguste Millet (1814?-1884), and Guillaume Marie Paul Louis Hurault Marquis de Vibraye (1809-1878). Clearly, these main characters had many formal and informal personal contacts, inside and outside the Societé. No wonder the 1840 restocking in l'Aisne could be organised before de Rivière actually presented his lecture.

10. Higginbotham (1997) provides a detailed description of Roman piscinae, including those for eel. Marsilius (1726) discussed whether eels occur in the Danube, mentioning in passing that live eels for sale in the market had escaped into the river. Hoffman (2005) describes the deliberate introduction of common carp for pond culture in medieval Europe; juvenile fish transport seeded only local reproduction ponds, and therefore must have involved relatively low numbers only. In Italy, lagoon fisheries have gradually developed into a system of extensive eel culture, over several centuries. Though these lagoons were an example for the French in the mid-1800s, long-distance transport of young eels developed only much later, in the wake of the French developments. For further details see Note 34. 
water plants or wetted straw; a fact-finding mission was sent out to gather available expertise; experiments were conducted at le Collège de France in Paris, using glass eel from the mouth of the River Orne - nineteen hours away by stagecoach, over a $200-\mathrm{km}$ distance; and practical instructions were published. Contrasting the opportunities in France to the well-established practices in Comacchio (northern Italy), France was considered to have a definite advantage 'in that glass eel is more abundant and earlier in the River Seine than in Comacchio'. ${ }^{11}$

The earliest eel restockings were mostly experimental, though the numbers involved could be incredibly high. In 1852, for example, 2.8 million glass eel from Nantes were restocked in an area with over 3,000 small lakes near Cour-Cheverny, involving the transport of approximately $800 \mathrm{~kg}$ of live eel over a distance of $230 \mathrm{~km}$. In 1854, a second experiment was held in the département of Aube (approximately $300 \mathrm{~km}$ from the coast, Aube remained a favourite area for Parisians; Figure 8). In 1857, 1.5 million glass eel were restocked in the Sologne. ${ }^{12}$ During these years, several shipments (large and small) are reported to have failed because of high mortalities of up to 100 per cent during transport. In 1853, the département of Isère reported that all their eel died, and instead decided to rely on artificial reproduction in future [sic]. In 1857, however, transport to Lac du Bouchet (44 ha, $350 \mathrm{~km}$ from the coast) was more successful 'thanks to the railways'. Though few authors actually reported the mode of transport, the link between restocking locations and railways remains evident; new restocking locations were often located near newly opened rail connections. Even the 'fish factory' in Huningue $(700 \mathrm{~km}$ from the coast) received a shipment of glass eel, sending them on to nearby places, including Haute-Saône, Doubs and Jura (Figure 8). We found no evidence of Huningue sending glass eel abroad, though delivery of their salmon stock to Germany and Switzerland indicates that contacts were cooperative.

Outside France, these achievements were well noted and people around Europe became aware of the potential for enhancing eel production. In several countries, experiments were set up. Overall, most of these early attempts

11. The essential report by Milne-Edwards (1850), commissioned by the Minister for Agriculture, summarises the scientific findings and suggests a development programme. Kinsey (2006) cited the word 'piscifactoire', but he did not name his source - nor could we locate it. On the occasion of the tenth anniversary of the Huningue facility, Coumes (1862) compiled an overview of production, transport destinations and further achievements, but his overview does not mention any eel. The early experimenting with eel packing, transporting, and rearing is described by Coste (1850), who summarised the acquired knowledge in a practical guidebook (Coste 1853a). Coste (1855) also reported on his fact-finding mission around Italy and France. The final optimistic quotation is from Pouchet (1856).

12. We found little detail (i.e. no numbers or exact destinations) for most of these early experiments, which unfortunately makes them disappear from our quantitative results. Nevertheless, the pattern of isolated experiments involving high numbers is clear. 
outside France were considered successes in that the eel survived and prospered, though none continued. ${ }^{13}$

By 1860, the techniques for catching, packing, transporting and culturing eel were well established ${ }^{14}$ - current techniques are hardly any different - and railroads across France connected all inland areas to the coast. Governmental bodies actively advocated restocking. Though early reports frequently discussed massive restockings at many locations, they rarely provide details on what was actually achieved. Most of what we know comes from the Conseils Généraux annually reporting on quantities delivered, above all from Bayonne. Were many more people restocking considerable quantities, and are the historical records for this period simply incomplete? In spring 1879, we find an upsurge in governmental involvement, via policies, instructions and legislation on eel restocking, preceding an increase in reported activities - which might indicate either that actual activity had increased or just that reporting had improved. In view of the spotty coverage of our information sources, we probably underestimate the true quantities involved. In any case, by 1879, the period of uncoordinated early developments had clearly ended, and a coherent national eel management plan was implemented.

\section{French national programme, 1879-ca. 1890}

This section discusses the French restocking programme beginning in 1879 . The almost synchronous German programme - covered in the next section did not notably influence the French actions.

In 1879, the ambitious but slowly developing practice of restocking in France suddenly changed: The government adapted existing legislation regarding season closures and minimal mesh size (Décret du 15 Juillet 1879, Ministère des Travaux Publics) to enable the glass eel fishery; put its employees to work catching glass eel in river mouths, even shortly before the fishing season and using otherwise prohibited fishing gear; and made the catch

13. Coste's practical instructions (1853a) were translated into English (Coste 1854a) and German (Coste 1853b), from German into Swedish (Coste 1854b); Duparc (1854) wrote a treatise on fish culture in Dutch, which for a major part was just a literal translation of Coste's original.

In 1858 and 1859, Baron von Washington (1862) imported 300 and 725 eels, respectively, from Triest to stock his fishponds at Schloss Pöls (200 km distant, along the Triest-Wien railroad); the Baron travelled all the way to Paris to report his success. However, his efforts seem to have ended there, perhaps because the Sardinian War cut him off from his resources in Trieste. Baron von Washington paid 12-24 Krone öW (Austrian currency) per pound $(\approx 250-500 € / \mathrm{kg})$, but that was for bootlace $(\approx 50$ grams each) rather than glass eel.

In 1862, fish culturist Hessel (Haack 1877b) stocked two ponds with eels at Iffeldorf (33000 eels) and Thalkirchen (250 eels), just south of Munich in the Danube drainage basin, approximately $900 \mathrm{~km}$ from the French coast; once again, there was no follow-up. Haack (1872) tried importing glass eels from northern France to Saalfeld in East Prussia (1,500 km distance), but without success. When Haack himself moved to southern Germany in 1871, he initiated a successful programme there.

14. Detailed instructions for transport and restocking are given in Anonymous (1860, 1864). 
available for restocking free of charge (though transport costs had to be paid). All départements were instructed to restock their waters (Circulaire de 20 octobre 1879, Ministère des Travaux Publics); within two years, the number of départements reporting restocking actions doubled and the total quantities rose from approximately 0.5 million to 2.5 million glass eel per year (Figure 3 ). This was a coordinated and effective governmental policy, which yet lasted only about ten years. The keys to understanding the late start, peak and early demise of this programme are likely found in the salmon programme, as we discuss below. ${ }^{15}$

Baron de Rivière gave his ground-breaking speech to the Société Royale et Centrale d'Agriculture in 1840, using the title Considérations sur les Poissons, et particulierement sur les Anguilles [Considerations on fishes, and the eel in particular] - which exactly expresses his line of reasoning: that the eel is a special case among fish in general. To improve the exploitation of aquatic habitats (which he compared to agriculture), he suggested developing 'la pisciculture', a term explicitly coined in this lecture, for fish in general and for eel in particular. Discussing pisciculture experiences, opportunities and anticipated problems (e.g. 'fish are difficult to transport alive'), he turned to the eel for just one reason: it was the feasible alternative to the more demanding salmon.

In 1850, the key to the French aquaculture programme was the discovery of the artificial reproduction of salmon and trout, i.e. the production of large quantities of young fish under controlled circumstances, enabling the live transport of eggs and very young fish. It is within this broader context of fish reproduction that the technique of eel restocking developed in the 1850s. Though all the preconditions for eel restocking had been fulfilled, the actual quantities restocked (a total of 13 million, 1855-1869) remained far below the production of salmonids in Huningue. That situation changed drastically in 1870, when the Prussians seized the Alsace/Elsaß in the Franco-Prussian War (1870-1871). The Huningue hatchery came under German rule (known as der Kaiserlichen Fischzuchtanstalt bei Hüningen im Elsaß) - a catastrophe for French pisciculture. Without the salmonid hatchery, eel was one of the few remaining options for developing the inland fishery in France. Four million eel were restocked in the 1870s, and once the government had amended its policies in 1879, 27 million eel were restocked in the 1880s. With salmon having been lost in the Alsace/Elsaß, the eel was again the feasible alternative. ${ }^{16}$

15. For this episode, we found no sources explicitly mentioning the price of glass eel. Comparing available budgets to the quantities acquired, the cost to the end-user was approximately $3-8$ $\mathrm{fr} . / \mathrm{kg} \approx 10-25 € / \mathrm{kg}$.

16. The production of young salmonids is estimated at 100 million between 1855 and 1869 (Bouchon-Brandely 1875, cited in Vivier 1956). The catastrophic effect of the loss of Huningue on French pisciculture is described in much greater detail by Kinsey (2006). For years, the French mocked rather than replaced the lost fish hatchery (e.g. de la Blanchère 1877). 
From 1879 to 1885, the aggregate volume of eel restocking increased rapidly, from 0.25 million to 4.5 million per year but, from 1885 onward, more and more départements complained that those restocked eels were eating all other young fish, particularly crayfish and salmon. This predation risk had been warned of long before, but that had not reined in the government's ambition (or frustration). In 1884, the département Haute-Vienne reported not having restocked, because 'all our rivers feed millions of eels that do us incalculable harm; one cannot deny us the right to defend ourselves'. Several départements asked permission to stop restocking, and the total restocked quantities soon dropped to the pre-1879 level of about 0.5 million per year, probably remaining that low for long afterwards. Whether eel restocking indeed negatively affected salmon production is doubtful: salmon stocking had crashed after the loss of the Huningue hatchery, and stocking had been unable to halt the ongoing decline of salmon stocks anyhow. In our view, the eel was blamed for unrelated developments in salmon stocks. Whatever the truth of the matter, the 1880 s eel-restocking programme ended, almost before it had contributed to the fishing yield. ${ }^{17}$

All in all, some 49 million individuals were restocked in France before 1900 - about fifteen tonnes of glass eel, producing some 1,500 tonnes of grown eel over half a century, about 100 tonnes annually in the peak years - a barely noticeable addition to the natural production.

The conventional view in eel research is that restocking began in the early 1900s and was centred in Germany. We have demonstrated above that the idea is of French origin and that a national restocking programme had been planned, implemented and negatively post-evaluated in France before almost any restocking ever occurred in Germany. The start of German eel restocking in the 1880s, however, had a completely different aim, namely, to seed the River Danube and the Black Sea with a self-reproducing stock. ${ }^{18}$

17. The potentially negative effect of introducing eel into salmon/crayfish areas had been described as early as 1865 (Soubeiran 1865). In 1878, even Millet - an early advocate of eel restocking - explicitly warned of the eel's voracity. Regarding salmon, at the start of the national eel restocking programme, de la Blanchère (1880) reported that the salmon stock was in decline. Many years after the downfall of eel restocking, Kreitmann (1938) once again reported an ongoing decline in salmon stocks. After the ending of the national eel restocking programme in 1890, regional programmes continued (e.g. Larbalétrier 1886; Le Clerc 1930), but without national coordination, until 2009.

18. Tesch $(1973,2003)$ reviews the literature on eel biology. Though he is not very explicit regarding the history of restocking, he mentions in passing that 'for transporting eels, gauze frames were already used in 1908 (Fischer and Lübbert, 1908)'. 


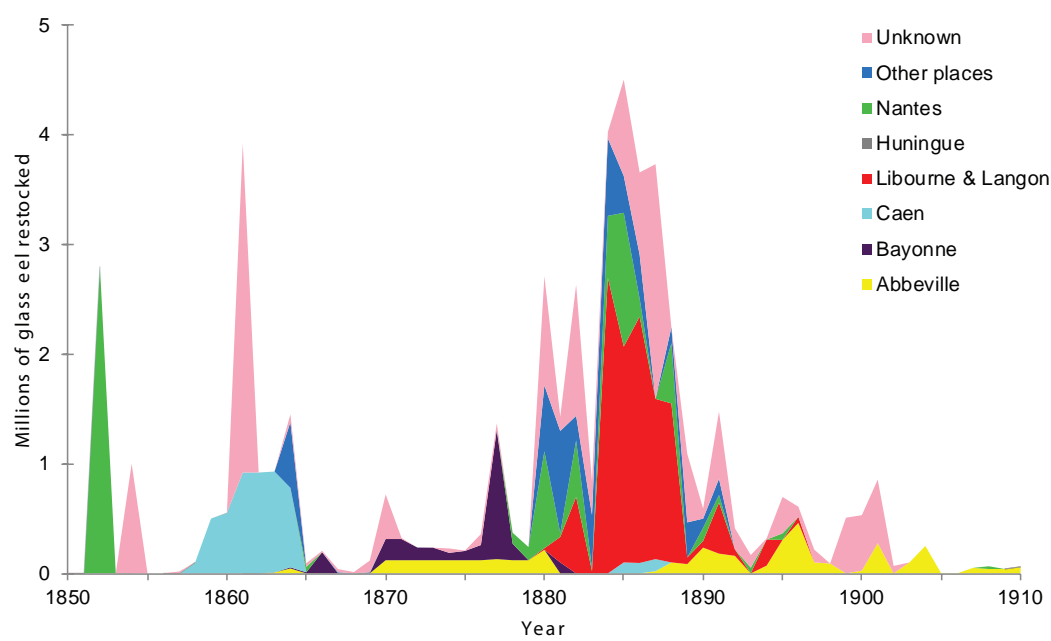

Figure 3. Temporal pattern of glass eel restocking in France between 1850 and 1910, by place of origin. The numbers represent the total over the départements for which we found documentation. Quantities were reported in many different units (e.g. paniers), which we converted using contemporary and/or modern documentation.

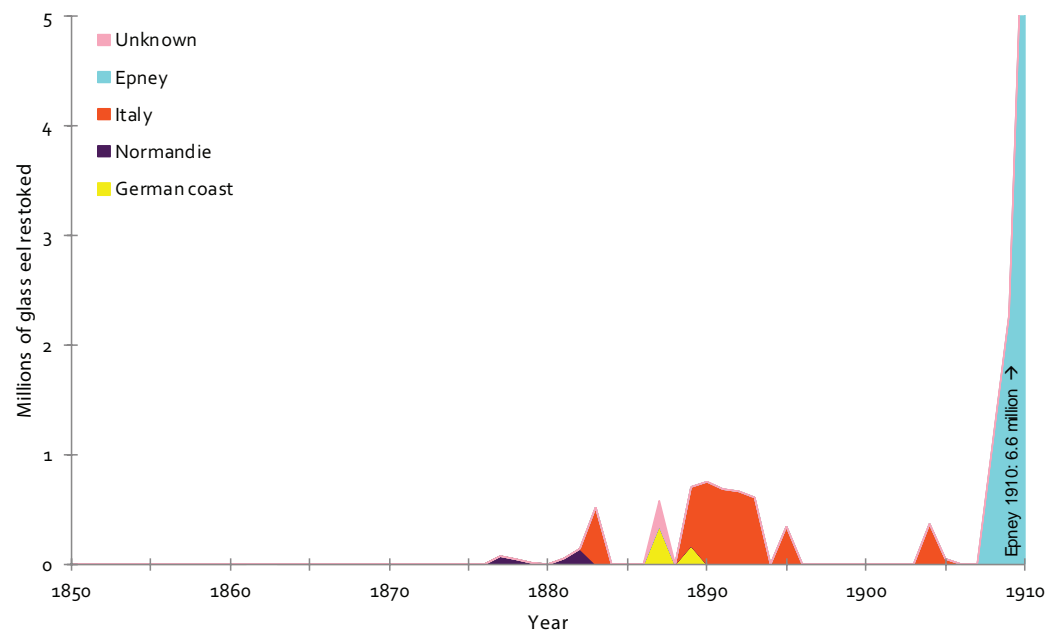

Figure 4. Temporal pattern of glass eel restocking in Germany between 1850 and 1910, by place of origin. 


\section{German programme to seed the Danube, 1881-1897}

When the technique of eel restocking developed in France in the early 1850s, local experiments were conducted in Austria, Bavaria and Prussia. Though the eel survived and prospered, no continued programmes were established. In 1871, this situation changed radically when Hermann Haack (1839-1905) was appointed director of der Kaiserlichen Fischzuchtanstalt bei Hüningen im Elsaß after the Franco-Prussian War. Hüningen (Huningue) still had its connections to the French railways and had an improving connection to Bavaria. Two French technicians - now employed by die Fischzuchtanstalt - ensured continuity in the operations at the Hüningen hatchery. In addition to Haack's salmonid efforts, he improved the transport methods for glass eel, tested his supply chain from France and, by 1877, he offered glass eel for sale in Germany. Compared with the French transport methods, Haack's main improvements were adding ice to the transport boxes and splitting the long journey with a refreshment stop in Hüningen. ${ }^{19}$

Though Haack nowhere explicitly said so, the strained political relations between France and Germany obviously troubled his supply chain. The salmonid achievements in Hüningen were well-known abroad, giving Haack an active network of contacts around the world. His publications were discussed in France as well, but only in translation, and we found no trace of any direct contact. His earlier eel supply from 'die Normandie' is nowhere described in detail, so he likely simply bought glass eel from random traders. In the late 1870s, glass eel from the mouth of the River Sèvre Niortaise were bartered for salmon fry from Hüningen, to mutual satisfaction, but that trade ended in 1880, when the French decided to use the glass eel for their own restocking. According to von dem Borne (1881) - referring to Haack's troubled imports from France - the absence of an adequate source of glass eel was the limiting factor for restocking in Germany. On the other hand, the French apparently never picked up the German idea of putting ice in the transport boxes. The exchange of expertise and glass eel, which had previously worked so well across Europe, had come to a standstill, blocking Hüningen's access to the main glass eel sources. ${ }^{20}$

19. The experiments in Austria (von Washington 1862), Bavaria (Haack 1877b) and Prussia (Haack 1872) have been described in the previous section on early experiments. Haack (1877a) promoted his success in Hüningen, boasting that his glass eel had survived a transport time of 24 to 72 hours. From the refreshment stop at Hüningen, all of Bavaria could be reached within 12-14 hours. Excluding the packing costs, he charged 12 Marks per thousand - approximately $155 €$ per $\mathrm{kg}$. In his own publications, Haack barely mentions the refreshment stop and gives no details of it. Meyer (1878) provides a colourful description of the premises in Hüningen, and mentions in passing the presence of a tank containing eel. Remarkably, he describes those eels as 'black-green' in colour, suggesting that Haack had either acquired somewhat older eel or had fed and grown glass eels for a long time.

20. Haack (born in 1839) was considerably younger than his French colleagues (from Coste 1807 to de Rivière 1817), and never acquired a doctorate. Representing the German conqueror of 
Then an unrelated technical breakthrough occurred: On 22 May 1882, the Gotthard railway tunnel opened between Italy and Switzerland, bringing new glass eel sources in Italy within reach. As early as the first months of 1883, Haack travelled to Pisa to buy glass eel (Comacchio had no railway connection yet). No longer was the German restocking programme via Hüningen dependent on the troubled French supply.

In the years shortly before, der Deutsche Fischerei-Verein - at the initiative of its chairman Kammerherr Friedrich von Behr (1821-1892) - had ordered glass eel for stocking in the River Danube (Donau), the objective being to establish a self-reproducing population in the Black Sea (i.e. seeding a new population, not augmenting a natural stock). This stocking programme fitted into a wider framework of introducing 'useful' species into the Danube. Accordingly, eel stocking occurred primarily in freely accessible tributaries of the river, not in closed ponds. The first year, only 30,000 French glass eel (approximately $10 \mathrm{~kg}$; Figure 4) were stocked. When the Gotthard tunnel had made Italian resources available, the numbers increased to over 0.5 million glass eel per year (i.e. $100-200 \mathrm{~kg}$ ). ${ }^{21}$

A considerable effort was made to monitor the results. When doubts were raised regarding the up-river stocking locations (which, it was feared, could result in only females being produced), half a million eel were transported in 1887 from Rendsburg to Galatz at the head of the Danube Delta (where production of males was expected), a total distance of $1,580 \mathrm{~km}$ covered in seven days. Though no evidence of reproduction was ever found, the Danube

the Elsaß, he faced an uphill psychological battle in establishing contacts to the grand old men across the border. In 1904, when der Kaiserlichen Fischzuchtanstalt was to be terminated, Haack (1904) reflected on fifty years of achievements in Hüningen, discussing both the French and the German periods in a remarkably friendly tone. He only blames the former French staff for removing the full archives (administration, instructions, protocols and procedure guides) at the start of the war.

In Germany, publications no longer referred to the newest French developments, but translated older French works; for example, Benecke (1880) and von dem Borne (1881) presented the work of Millet (1870) describing the 1840s experiments. Experiments in central Germany used extremely low numbers (e.g. 5,000 glass eels in a 76-ha pond near Braunschweig; von dem Borne 1881), resembling the early French experiments almost twenty years before.

In France, information on the developments in Hüningen was acquired from the 1880 International Exposition in Berlin (Raveret-Wattel 1883), rather than from direct contacts across the border. In Berlin, Haack had demonstrated a transport box for salmon eggs with ice on top, resembling the boxes he used for transport of glass eel. Though French packing instructions had become much more detailed in 1884 (Gauckler 1884) than in 1860 (Anonymous 1860), their technique had not changed at all.

21. Haack (1883) gives detailed accounts of his exploratory trips to Italy, which soon developed into routine transports.

Details of the early stocking in the Danube can be found in Haack $(1881,1882)$. According to Hofer (1897), the eel stocking project was initiated by Kammerherr Friedrich von Behr (1821-1892), the Chairman of the Society, though most of his articles were published anonymously. 
stocking programme was generally considered a success as the eel survived and prospered in the river. After Androussow published that the Black Sea is already oxygen depleted at a depth of a few hundred metres, it was soon realised that a naturally reproducing eel population in the Black Sea would be unachievable. Though it was considered not absolutely impossible that the eel might reproduce in fresh water, the stocking programme in the Danube was rapidly scaled back. The trade in glass eel via Hüningen continued at a very low level, for stocking in ponds, and came to a complete end only days after Haack's retirement and sudden death in summer 1905. ${ }^{22}$

Over a 25 -year period, some 5.5 million glass eel were stocked via Hüningen, predominantly coming from Italy and mostly released into the River Danube. This represented almost two tonnes of glass eel, producing a total of approximately 200 tonnes of grown eel, about ten tonnes annually in peak years. Though these eels must have lingered in the Danube system for decades, the total production is too low to have any further significance. A selfreproducing population was not established in the Black Sea.

While the Danube stocking programme blossomed, various eel-related lines of discussion evolved all over Germany. First, it was realised that 'modern' barriers blocked the migration of young eel. Those barriers are nowadays considered old-fashioned ones, too small and leaky to impede fish migration very much, but their effects were considered worrisome at the time - in our view, rightly so. Discussions of how to minimise or work around such barriers were mixed with discussion of the best type of stocking material (i.e. glass eel vs. bootlace eel, that is, the youngest vs. half-grown recruits), the best sources (i.e. the northern German coast, France, or Italy), acceptable transport distances and times, etc., suggesting a confusing debate based on general north-south rivalry in Germany. When der Deutsche Fischerei-Verein decided to stock the downstream location of Galatz in 1887, Haack and northern suppliers made competing offers. Transport was organised from Rendsburg, 1,580 km away, while Haack would have stocked from Trieste - closer but still 1,100 $\mathrm{km}$ away. Twenty years later, when the next restocking programme had already made a successful start, the Hamburgians Fischer and Lübbert (1908) still denigrated Haack's achievements. In the 1880s, however, chairman von Behr was

22. Hungarian fishers were encouraged to report 'a snake-like fish that looks somewhat like a lamprey' for a significant reward (Anonymous 1888a); large eels on the market in Sulina, at the mouth of the River Danube, were verified (Anonymous 1889); hearsay reports of montée being observed at Kilija, the most northerly branch of the Danube Delta, were tested in vain by offering high rewards for any evidence (Anonymous 1889); a large eel was reported from the Dnjepr River, Ukraine, $250 \mathrm{~km}$ from the Danube (Anonymous 1891), etc.

Androussow (1897) describes the geological and hydrological conditions in the Black Sea. Considering that eels spawn in deep water (Grassi and Calandruccio 1897), Hofer (1897) drew the biological conclusion and realised that they could not reproduce in the Black Sea.

Binnert (1998) provides an account of the history of the Hüningen station, including some details on Haack personally. 
unrelenting: it was imperative to stock the Danube, but to restore the natural migration routes for eel in the north - 'Bahn rein! für die Aalbrut' (Open the track! for the young eel; Anonymous 1888b). ${ }^{23}$

Though von Behr strictly controlled the action taken, he could not completely block discussion, and restocking northern waters remained a tempting option. After the failure of the Danube programme in 1897, Elsner (1899) advocated restocking all suitable waters in Germany, ${ }^{24}$ but without an adequate source of glass eel, this remained merely a dream. Then, in 1906, Schmidt published an article on the life history of the eel in which he stated (p. 247), 'I think that the Baltic countries and the Danish waters should be provided with great quantities of young eels from the Atlantic coasts', naming England and Ireland as potential new sources. Frustrated by the Danube failure, bad relations with conventional glass eel sources in France, and the strictness of Behr's 'Bahn rein!', the Naturwissenschaftliche Verein in Hamburg spotted a hitherto unknown opportunity in England, and embarked on a new journey.

German programme from Epney, 1908-1940

In 1907, developments in eel stocking came quick and fast. On 6 February 1907, Hans Lübbert (1870-1951) gave a lecture for the Naturwissenschaftliche Verein in Hamburg, presenting the ideas of Schmidt (published in October 1906). Though Schmidt, himself half Danish, had discussed 'the Baltic countries and the Danish waters', Lübbert quotes 'not only in inland waters, but also in the Baltic Sea', implicitly emphasising inland waters. Only half a year later, in August 1907, the Deutsche Fischerei Verein organised an exploratory trip to England. The following spring, in 1908, over a million glass eel were shipped from England to Germany, and quantities rose to a new peak of over five million in 1910. The Deutsche Fischerei Verein established a storage and packing station on the shores of the Severn Estuary in the Anchor Inn at Epney. Glass eel collected by local fishers were packed in wooden boxes with ice on top, then sent by train to Grimsby and from there by boat to Hamburg. In Hamburg the glass eel were refreshed in water, repacked and sent on by train

23. Haack offered glass eel for approximately 10-15 Marks per thousand. Fischer and Lübbert (1908) blame him for this high price, but their own offer was ultimately slightly more expensive. In addition, they blame Haack for running the glass eel business on a personal basis, neglecting the fact that the Deutsche Fischerei Verein had asked Haack to do so.

The earliest reference to an eel ladder we found is from von Benecke (1884), though it is not clear whether he developed the idea himself. He refers to earlier work in Ireland and Schleswig, but without providing any details on what was done there.

24. Discussing the future prospects of eel restocking after the Danube debacle, Elsner (1899) actually suggested a complete infrastructure of distribution centres, train services, and regulated prices, serving all of Germany. 
to destinations all over Germany and neighbouring countries - as far east as Königsberg and as far south as the Bodensee. ${ }^{25}$

Though the Epney glass eel was considered extremely cheap, the success of the overseas transport also renewed interest in local sources on the German coast, for example, Hoyer/Højer, Neuharlingersiel and, after 1927, Herbrum on the River Ems. In times of war, these coastal locations were the sole sources available.

The key to this rapid development was the 'discovery' of rich English glass eel resources considered infinite; otherwise, the techniques resembled those previously used in France and southern Germany. Overwhelmed by their own success, the restockers eventually completely reversed their initial objectives: no longer was restocking considered compensation for blocked natural immigration routes, but blocking every river was advocated to enable the capture of all glass eel for restocking. ${ }^{26}$

In 1909 and 1910, over 200 destinations, mostly small ponds next to castles or mansions, were restocked, most locations being served only once. By the mid-1920s, only fifty larger lakes remained, mostly on an annual basis. The Deutsche Fischerei Verein also initiated and supported transports to other countries (Figure 9), in early years to Denmark, Finland and Sweden, but in the 1920s and 1930s also to England and Ireland, Holland, Poland, Czechoslovakia, Latvia and other countries, sending nearly half the total volume abroad. International collaboration in eel restocking, which had come to a standstill after the Franco-Prussian war (1870-1871), was re-established, though not including France. This interbellum cooperation is all the more remarkable because World War One had ended German operations in England. In 1924, the operations resumed and expanded, restoring the international cooperation. In the early days of World War Two, however, the transport of glass eel from England to Germany came to a complete standstill and German property in England was forfeited again. Almost the entire 1940 catch was shipped to the Netherlands, giving the Dutch an unprecedented dominance, which they

25. For a detailed account of early eel shipments from Epney to Germany, see Lübbert (1907), Fischer and Lübbert (1908) and Lübbert (1910).

From 1907 to 1910, alternative routes via Plymouth, Harwich and Cuxhaven, were tried. Grimsby had a reliable daily ferry service to Hamburg, operated by the Great Central Railway Company. This company ran the Epney-Gloucester-Grimsby train service as well, making the apparent detour worthwhile. The travel time was eight hours by train plus one hour in harbour plus 31-36 hours by ferry for a total of 40-45 hours (Lübbert 1910).

On the German side, a repacking station was equipped, first in Cuxhaven, soon in Hamburg-Altona. The current Deutsche Fischerei-Verband still operates an eel repacking station, der Aalversandstelle, in Halstenbek.

26. H. Henking makes the reversal of objectives explicit in a postscript to Eichelbaum (1924). Fischer and Lübbert (1908) estimate the price for the end-user at 15 Marks $(\approx 180 € / \mathrm{kg})$ per thousand. In the 1920s and 1930s, a stable price of approximately 20 (Reichs) Marks per thousand $(\approx 40-85 € / \mathrm{kg})$ is frequently mentioned, despite economic fluctuations. 
quickly regained in 1946. German leadership on eel restocking ended then and it has never been restored since. ${ }^{27}$

From 1908 to 1940, a total of 174 million eel were used for restocking (approximately fifty tonnes), mostly derived from Epney. In the peak years of the 1930s, ten million eel annually were restocked (Figure 5), for an estimated yield of approximately 300 tonnes per year - far below the total production in Germany. ${ }^{28}$

After World War Two, the expertise developed in the Epney programme - shared with neighbouring countries in the 1930s - set the stage to raise eel restocking to sky-high levels.

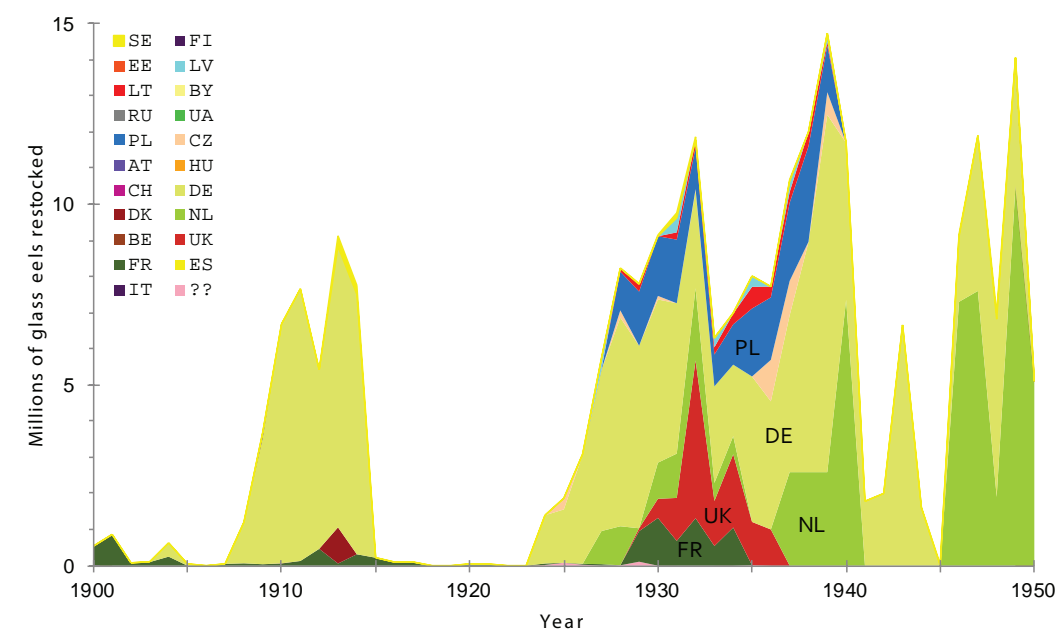

Figure 5. Temporal pattern of glass eel restocking between 1900 and 1950, by destination country. Countries are identified by their Internet codes.

27. Lübbert (1910), Lübbert and Fischer (1911) and Lübbert (1925a,b) tabulated their deliveries, including the destination locations (i.e. place, address or water body). We located those places, using any information source available on the Internet. The places in former eastern Prussia, which are now known by their Polish or Russian names, were often difficult to find. The destinations of $4 \%$ of the deliveries (3\% of the glass eel numbers) could not be located beyond doubt. Lübbert (1910) and Nordqvist (1928) document the early period of international redistribution, Röhler (1939) the later period.

28. Statistics on landings have been collected systematically by the FAO back to ca. 1930, but German statistics are only available since World War Two; see Dekker (2003b) for details. Röhler (1933) provides a detailed but not precisely dated estimate for the total German fishery of 107,000 Zentner (5,350 tonnes). FAO reports for Germany after World War Two start at 100 tonnes, rise to 2,100 tonnes in 1963, then slowly decline parallel to the general stock decline (Figure 2). The earlier FAO data for Germany are obviously far from complete. 


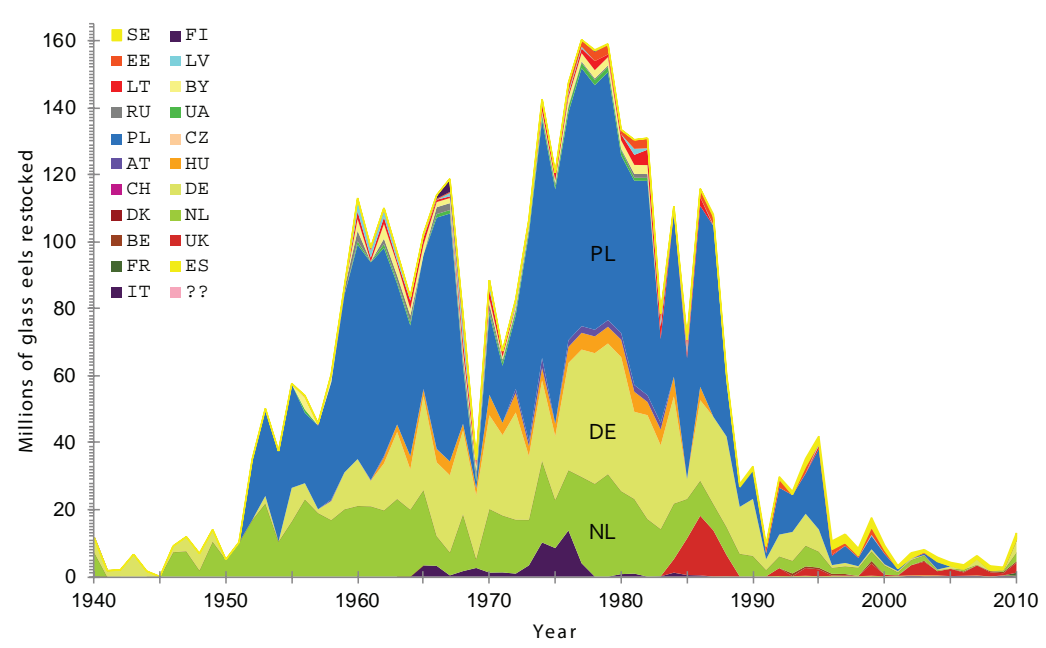

Figure 6. Temporal pattern of glass eel restocking between 1940 and 2010, by destination country. Countries are identified by their Internet codes.

Heyday and downfall after World War Two, 1945-2000

In 1946, actions underway shortly before the War simply resumed, but all players soon had to reconsider their positions. Imports into Germany were not allowed, and wartime sources in Denmark were no longer available to the Germans. Effectively, Germany was banned from its own restocking programmes for twenty years, until 1965, so redistributing glass eel from its national source in Herbrum was its only option. ${ }^{29}$ The Netherlands had taken the opportunity in 1940 to seize the major share of the Epney glass eel, and did so again from 1946 onwards. In the early 1950s, however, unexpected competition for the limited supply from Epney necessitated refocusing on new French sources, and overland transport by car became the standard route for the Dutch. Poland - a secondary player before the war - lost its supply via Hamburg and had an unacceptably-long ferry connection to England. In 1952, however, Bolesław Dąbrowski (1911-1997) announced a great technical breakthrough: air transport from France covering 1,750 km within 24 hours. ${ }^{30}$ In one step, a major restriction on eel transport was eliminated, bringing distant sources (i.e. France and Spain) within reach. France - not involved in international

29. Meyer (1951) did not hide his deep regret at Germany's loss of Epney glass eel, and advocated developing Herbrum to the maximum.

30. Dąbrowski (1952) analysed the effects of the 1920s restocking into the Masurian Lakes (then part of Germany), concluding that restocking was the main basis for the eel fishery there. $\mathrm{He}$ then documented the 1952 air transport route in detail: from Montoir-de-Bretagne at the mouth of the River Loire by train to Paris, then by plane to Warsaw. 
restocking since 1870 - regained an important position, becoming the main source of glass eel. The eel's alleged voracity - held against it by the French in the 1880s - was considered a strength in Poland, enabling it to devour useless sticklebacks, ruff and perch. With supply no longer the limiting factor and prices dropping to an all-time low, Dąbrowski calculated the quantity needed to restock all available habitats in Poland (sixty million annually). Within ten years, imports indeed rose to fifty million glass eel - Elsner's (1899) dream of a complete restocking industry had come true, at least in Poland. Other Eastern Bloc countries copied the Polish success (Kokhenko 1969; Figure 6 and Figure 10), as far south as Georgia (3,500 km from the French sources) and as far east as Orenburg (over 4,000 km away), though restocking in other communist countries was never as extensive as in Poland. Though countries competed on the glass eel market, they often shared their expertise. ${ }^{31}$

In addition to glass eel, several countries used bootlace eel for restocking. Historically, bootlace numbers constituted only nought to ten per cent of the glass eel numbers, and bootlace eel were acquired from national sources. When glass eel numbers declined after 1980, bootlace numbers did not decline equally, and in recent years, numbers of glass eel and bootlace almost tallied. Since the patterns of bootlace restocking generally differed little from those of glass eel, we do not further elaborate on this, except for the following cases. In Sweden (and less so Estonia and Latvia), locally available bootlace eel became more important than glass eel imported over long distances but, after 1970, the proportion of glass eel used in restocking slowly returned to 'normal' levels. Most of these bootlace eel came from national sources (Trollhättan) or from nearby Swedish or Danish coastal fisheries. In Italy, bootlace imports from France exceeded the redistribution of glass eel within the country from about 1980; since 2000, numbers tally.

In the 1960s, air transport of glass eel became so successful that worldwide transport became an option and, in 1969, the Japanese started buying glass eel in Europe. Sharply rising prices disturbed the markets but in the early 1970s the Japanese approached suppliers closer to home, and European restocking quickly restored. ${ }^{32}$

31. Janis Birzaks (Latvia) and Tomasz Nermer (Poland) have indicated in personal communications that Poland, which, unlike the Soviet Union, had an open trade with the West, was even developing the eel fishery to acquire western currency.

We found no contemporary information on glass eel prices between 1950 and 1980. In 1996, when the price had already increased twenty-fold, ICES-WGEEL (1997) reminisced about past developments, reporting a price of $40 \mathrm{Dff} / \mathrm{kg}(\approx 43 € / \mathrm{kg})$ for Dutch end-users in 1980.

32. Briand et al. (2008) report a price of up to $500 € / \mathrm{kg}$ in 1969 , and describe the collapse in demand on the French market when the Japanese left; Don Jellyman (pers. comm.) confirms the arrival of Japanese traders on the New Zealand market at the same time. In the decades since, non-European demand for European glass eel has continued (Ringuet et al. 2002), but has never had such a noticeable effect as it did in 1969. 
The level of restocking continued to increase until the 1980s, when the supply of glass eel began to diminish. Though the need to support the distressed eel fisheries by increasing the amounts restocked was often emphasised at this time, the annual restocking budget actually declined. In fact, restocking quantities from 1952 to 2009 exactly reflect the trend in recruitment; neither the increased price nor the increased competition on the market after 1980 had any noticeable effect. ${ }^{33}$

From 1945 to 2000, a total of 3,682 million glass eel were restocked, representing more than 1,200 tonnes, corresponding to an estimated fishing yield of 120,000 tonnes. In the peak years of the 1970s, 150 million glass eel were restocked each year (Figure 6), producing an estimated 5,000 tonnes annually. In Poland and other Eastern Bloc countries, almost the whole national production was of restocked origin.

While restocking supported the development of the eel fishery after the War, this successful development gradually led to a competing use of glass eel for aquaculture.

\section{From fishery to aquaculture, ca 1980-present}

For modern observers, there seems to be a clear distinction between fisheries and aquaculture, fisheries exploiting wild stock in outdoor waters, while aquaculture operates in indoor tanks, using recirculated water, artificial feed and imported seed. In Figure 2 we showed this distinction, presenting the available data at face value. Considering the matter in greater detail, however, the distinction between the two becomes less clear, there being a smooth continuum: from wild eel fisheries in unmodified natural habitats, via modified habitats and artificial ponds, to indoor tanks; from wild stocks, via supplemental restocking and put-and-take fisheries, to full confinement; and from northern fisheries making a long winter stop, via lagoon culture in warm southern countries, to heated and recirculated water systems used indoors. In other words, restocking, as discussed here, and the use of wild youngsters for aquaculture are not fundamentally different. In fact, the eel culture in Comacchio in Italy, in which the fishers heavily managed both the habitat and stock within a natural

33. We have found no written sources pleading for increased restocking levels, but have ourselves frequently participated in discussions of this matter. Thurow (1979) advocated restocking and an improved assessment of stock conditions, with reference to the ongoing decline of the continental stock - the collapse in recruitment from the ocean had yet to occur.

We calculated the total budget based on total quantities used for restocking (Figure 6) and the first-hand price of glass eel reported by Briand et al. (2008). According to Briand et al. (2008), the price started to increase ca. 1980 , reaching $400 € / \mathrm{kg}$ or more in the early $2000 \mathrm{~s}$ - though this reflects the development of the first-hand price only. 
environment, has long been regarded in France as a glorious example of wild stock management. ${ }^{34}$

Following Coste's exploration of Italian eel fisheries, Pouchet discussed two options for developing eel fisheries in France, 'immediate' and 'mediated'. The first option was to create habitats where glass eel recruitment is naturally abundant; in 1863, sixty earthen ponds constructed along the River Seine near le Havre were stocked from the river, only $250 \mathrm{~m}$ away. The second, mediated, option entailed trapping the incoming glass eel and transporting them to distant habitats; in 1852, Vibraye transported 2.8 million glass eel from Nantes to existing lakes near Cour-Cheverny, a distance of $230 \mathrm{~km}$. Though we find examples of pure aquaculture and pure restocking, most historical sources remain unclear about how they approach the matter: Pouchet's sharp distinction between the immediate and mediated use of the glass eel might have been rather artificial. ${ }^{35}$

Four aspects of modern aquaculture are relevant to the current discussion of restocking. First, the whole concept of restocking was originally inspired by contemporary pond culture. By exploiting natural habitats rather than ponds, one could increase production considerably, to feed the poor.

Second, since artificial reproduction of the eel is not feasible, all eel aquaculture depends on wild-caught glass eel (or bootlace eel, in the 1980s), making aquaculture a direct competitor of restocking on the market for glass eel. Since 1980, the simultaneous decline in supply (Figure 2), rise in price, and increasing competition for glass eel (for aquaculture, Figure 1) came with a severe reduction in the quantities restocked (Figure 6) - though it is not absolutely clear which was the cause and which the effect. ${ }^{36}$

Third, in Sweden and Finland, the aquaculture industry has provided facilities for quarantining imported glass eel. This service by the aquaculture industry has facilitated glass eel imports, but otherwise affected the glass eel

34. Coste (1855) and Pouchet (1856) describe the Comacchio stocks as an example of how effectively eel stocks can be managed. Available information (Ardizonne et al. 1988; Rossi and Cataudella 1998; Ciccotti et al. 2013; Eleonora Ciccotti, pers. comm.) does not allow a quantitative reconstruction of the eel fishery and culture in Italy, especially since a major part of the lagoons is privately owned, and thereby undocumented. For centuries, the water regimes in the lagoons near Comacchio, Venice and elsewhere in Italy have been manipulated, influencing the productivity and natural recruitment of glass eel. In addition, eel has been imported from other national sources such as the Italian west coast (e.g. Rome and Pisa), foreign eel having been imported only recently. In historical times, almost all eel were probably recruited and/or trapped locally. We found no evidence of eel transport of any considerable size until the mid-1900s, when considerable quantities of bootlace eel were imported from southern France.

35. These two options, i.e. immediate versus mediated, were discussed by Pouchet (1856). Gobin (1889) described the ponds near Le Havre and Vibraye (1854) described the eel transport to Cour-Cheverny.

36. In 2012, 16\% of the total catch of 154 million glass eels (52 tonnes) was used for restocking, $42 \%$ for aquaculture, and $42 \%$ for unknown purposes (ICES-WGEEL 2013). 
only minimally (typical release is after six weeks at a maximum size of ten centimetres). ${ }^{37}$

Finally, aquaculture has been a source of restocking material. In the 1980s, the slow-growing individuals were sorted out from aquaculture stock and sold as cheap material for restocking. Since the mid-1990s, glass eel have also deliberately been 'pre-grown' in aquaculture for restocking purposes. The pre-growing of glass eel should prevent high initial mortality in the youngest stages. This improved survival was initially considered a purely economic benefit; later, however, it was claimed to constitute a major advantage for the eel stock itself in the next episode: the European eel protection and recovery plan. ${ }^{38}$

\section{Renewed interest - new discussions, 2009-present}

The decline of the eel stock in recent decades (Figure 2) eventually led to the adoption of a European protection and recovery plan, known as the Eel Regulation. Within a range of potential protective measures (e.g. fisheries restrictions, habitat restoration, predator reduction and reducing mortality in hydropower plants), the Regulation pays particular attention to restocking (Article 7), declaring that up to sixty per cent of the glass eel catch should be reserved for restocking to increase silver eel escapement. In many cases, it is not quite clear whether the restocking is meant to compensate for other anthropogenic impacts (e.g. the hydropower industry restocking coastal waters to compensate for hydropower-related mortality in inland waters, as in Sweden), to support a fishery that is under restrictions (e.g. restocking while maintaining the fishery, as in Germany) or to contribute unselfishly to stock recovery (e.g. governmental restocking of unexploited waters, as on the west coast of Sweden). In most cases, the actions are well-specified, though the objectives remain unclear. Within a year of the 2009 implementation of the Eel Regulation, the total number of glass eel used for restocking had risen from three to thirteen million or more (Figure 6). ${ }^{39}$

37. The quarantining procedure has never actually been published (Håkan Wickström, pers. comm.). In 2013, nearly three million glass eels were quarantined (ICES-WGEEL 2013).

38. It is not absolutely clear where and when the practice of 'pre-growing' started; Baer et al. (2011) specify that it has been going on 'for several years'. Over the years 2009 to 2012, a total of some 91 million eels have been restocked, $50 \%$ of which were pre-grown in aquaculture (ICES-WGEEL 2013).

39. Anonymous (2007) describes the Eel Regulation itself; Dekker (2008) described the process leading towards adoption.

Most EU Member States have included restocking as a management action in their national Eel Management Plans (ICES-WKEPEMP 2013). The 13 million glass eels actually used for restocking in 2010 were far fewer than the aggregate target of the national Eel Management Plans, i.e. 40 tonnes, equivalent to approximately 120 million glass eels (ICESWGEEL 2011). ICES-WGEEL (2012, p. 107) provides details of the national restocking programmes and highlights ambiguities in the available information. 
Up to 2009, restocking was conducted to attain various objectives but, in all cases, the ultimate target was to increase eel production in continental waters. The Eel Regulation defines a new purpose, targeting a new location: to increase silver eel escapement to the sea, ultimately contributing to reproduction in the Atlantic Ocean. Whether or not restocked eel are able to migrate to their spawning places has been questioned. We abstain from analysing this ongoing scientific debate, while noting that the discussion continues at EU and national levels, in politics and among scientists. How that discussion will end remains to be seen - our historical overview of eel restocking ends here. ${ }^{40}$

\section{FAIRE MIEUX QUE LA NATURE}

In the second half of the 1800 s, the stocking of salmon and other fish developed, in France and around the world. The material presented here indicates that the restocking of glass eel was actually the forerunner of this development, that the glass eel was the feasible alternative to the more demanding salmon and that eel restocking has continued in parallel to the artificial production of many other fish species. What were the objectives of eel restocking, have they actually been achieved and what were the key factors affecting that achievement?

\section{Aims, actions, and achievements}

Very few historical publications explicitly spell out the intentions underlying restocking; more often, authors described the aims of specific actions, focusing on only parts of the restocking process. However, actions, context, and expressed expectations often allow us to deduce the implicit objectives.

In very early phases, at the times of the Roman piscinae, the medieval ponds/containers in central Europe and the initial years of restocking from Epney into castle ponds in Prussia, there seems to have been little point in raising eel other than as curiosities, as an exceptional kind of ornamental fish or an extraordinary food item. The costs of eel transport and raising (Table 1) were simply disproportionate to the production achieved. But, we admit, the eel is a weird fish and good food indeed.

Over the 175 years, that restocking has now been practised, its prime objectives have been to maintain, restore or increase eel production in rural areas. These objectives have been formulated in terms of food production, employment and habitat exploration, but in recent years the focus has shifted to stock

According to ICES-WGEEL (2013, p. 128), the price of glass eel in the source countries varied between 300 and $500 € / \mathrm{kg}$. We know of no recent statistics on the price to end-users.

40. Westin (1998) experimented with tagged eel of restocked origin in the Baltic Sea, finding that the restocked eels did not find the exit of the Baltic Sea. Van Ginneken et al. (2005) analysed the magneto-sensitivity of eel, and questioned the ability of translocated eel to return to the spawning ground. 


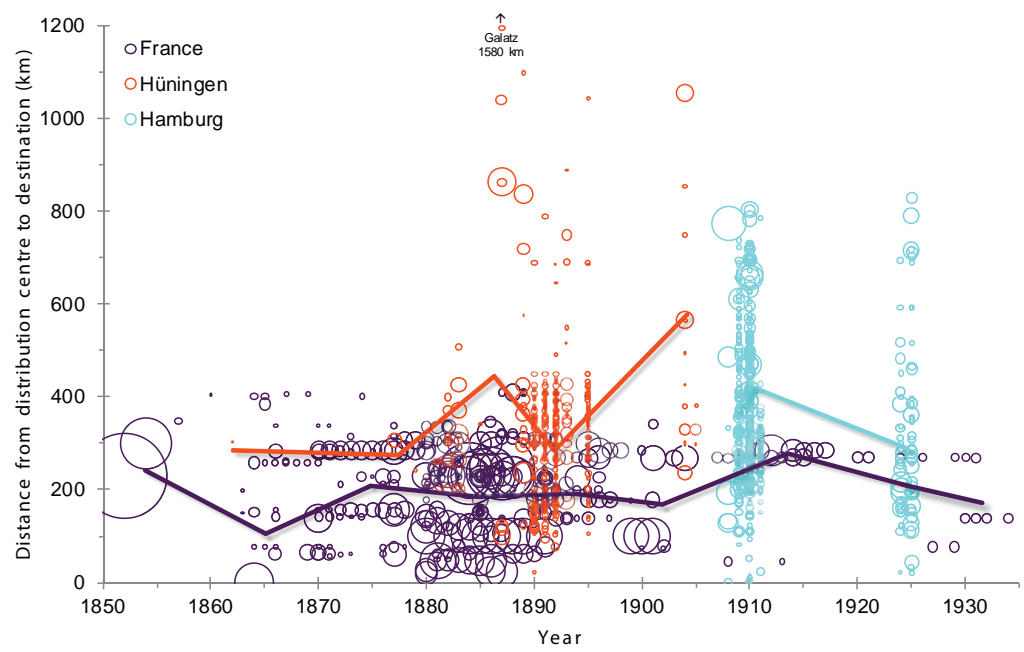

Figure 7. The development of eel transport distances over time, from the distribution centres (indicated by symbol colour) to the final restocking sites. The size of each symbol corresponds to the number of glass eel restocked; for France, that is the number per département per year, while for German transports, it is the number per individual delivery. Distances are calculated as great circles (i.e. as the crow flies). In France, glass eel were supplied by many centres; if no supplier was specified, the nearest location on the coast was assumed. Information on the German restocking in 1912-1913 is available but incomplete and is therefore not shown. The lines connect decadal means, weighted by the number of glass eels involved.

recovery. From Baron de Rivière to present day Eel Management Plans, the objectives have changed, but the expertise, techniques, transport, most stakeholders and public discussions have remained largely the same. Across these years and all over Europe, one element is shared by all these objectives: by artificially redistributing young eel, the intention has been and is to improve the local and/or global situation, to augment the natural abundance, to extend the natural distribution area, to improve the exploitation of available habitats, to increase control over the stock and improve growth and survival - in other words, 'faire mieux que la nature' [to do better than nature]. ${ }^{41}$ Though we might be anachronistic in doing so, we will evaluate here whether 'mieux que la nature' has actually been achieved, and what factors have enabled or hampered this. Our evaluation will focus on the net results achieved, not on

41. Though 'faire mieux que la nature' has been the leading principle of technical development in agriculture and aquaculture, it turned out to be difficult to find sources using exactly this wording in relation to the eel. Godenier (1852) uses 'faire incontestablement mieux que la nature' in relation to the artificial reproduction of salmon. Much more often, it is used to state the opposite ('vous ne ferez pas mieux que [la nature]'; Noël 1856) - in modern times, this negative wording is frequently cited in public discussions of genetically modified organisms. 
the biological processes and economic mechanisms involved (growth and survival, competition and cost-effectiveness).

\section{Source, transport and destination}

The abundance of glass eel along the Atlantic coast of France (north up to Brittany) was so high that Coste (1849) believed it would suffice to restock all the waters of the world [sic], but restocking has never actually used more than a tiny fraction of the total glass eel supply (Table 1). The abundance has never restricted the development of restocking, but the supply has always been spatially concentrated and the opportunities for transport severely limited. Additional sources occurred along the northern shores of France, the west coast of Italy and in the Severn Estuary (Epney). Portugal and Spain did have glass eel resources, but were effectively net importers. In the early years of the River Danube stocking, inland sources were considered. ${ }^{42}$ Though the eel stock obviously used to be much more abundant than anyone can imagine nowadays, the quantities and reliability were still considered inadequate. Local sources along the coasts of Sweden (bootlace), Germany, Denmark, the Netherlands, Belgium, Ireland and western Italy have all had some relevance, but predominantly in times of political constraints on the main sources. Almost all of these local sources operated with governmental support, indicating that low abundance did not really allow cost-effective exploitation. After World War Two, the import of glass eel into Germany was blocked for political reasons and the local source in Herbrum on the River Ems was fully exploited. As soon as these political restrictions were lifted in 1965, almost 24 million glass eel were imported from France, while exploitation of Herbrum fell from fifteen million to five million glass eel within one year and was rapidly abandoned after 1980 (see Figure 2, 'Ems'). These smaller local sources have been only of secondary significance. The Atlantic coast of France was and is the main source of glass eel in Europe, with a supplementary quantity from Epney.

The history of glass eel restocking can be read as a story of transport modes and technical developments: the French programme of 1850-1890 was enabled by the newly opened railway; the German programme of stocking the River Danube was feasible thanks to the train connection through the Gotthard tunnel; the Epney programme of 1908-1940 relied on well-organised international ferry transport; and, finally, Poland's successful air transport in 1952 broke down all limits imposed by means of transport. Over the 1850-1940 period (Figure 7), the average transport distance from distribution centre to final

42. In the upper reaches of the River Rhine, masses of migrating eel had been observed (Anonymous 1884), for example, at the waterfall in Schaffhausen. The abundance of eel in Baden (just north of Basel) was so great that local people were aware of the weather conditions triggering eel migration ('With the first thunderstorms, the eels are coming'; Anonymous 1887). 
destination hardly changed. Special transport to distant places, such as Galatz in 1887 at $1,580 \mathrm{~km}$ from the source, simply required extra care. Promising new programmes (e.g. the Epney programme) often prompted excessively long transport to distant places in their first years (e.g. castle ponds as far east as eastern Prussia in 1908) but, after the first over-optimistic years, transport distances returned to normal values. Large-scale transport from the original sources to intermediate distribution centres increased the total distance from source to destination, but the fine-distribution from the distribution centre to the end-user was still the limiting factor. In conclusion, realistic transport distances for live eel limited the further expansion of restocking.

Available destination habitats for restocking are most abundant near coasts but, being near the sea, they generally faced no lack of eel. Probably more important than this distance-to-the-coast pattern is a latitudinal trend in lake abundance, permanent lakes being more abundant in northern mainland Europe and particularly in Scandinavia. The north-south rivalry in Germany in the late 1800s was not only a debate between the haves in Hüningen and the have-nots in the north, but also between the easily satisfiable Bavaria and the insatiable Prussia. The north itself was struggling with migration barriers (e.g. weirs, dams, and sluices) that increasingly hindered natural recruitment, creating low-abundance destination areas for restocking themselves. Were these barriers to be mitigated, using eel ladders, or compensated for by restocking? Mitigation measures being too little, too late - as usual - compensation by restocking has become the preferred measure. A fortiori, one considers restocking nowadays almost as a conditio sine qua non for the occurrence of eel in these areas. In summary, the plentiful habitats in northern Europe where eel had formerly been abundant were and, to some extent, still are the prime destination areas (Figure 10)..$^{43}$

Given the spatially limited glass eel source in France and the technically limited transport distance (approximately $400 \mathrm{~km}$, realistically), the abundant habitats in northern mainland Europe have long remained out of reach. Scandinavia's abundant lakes have remained fully out of reach for such a long time that Sweden kept to its national bootlace sources for decades, only joining in international restocking efforts when the supply had already started to decline (Figure 6).

43. Dekker (2003a) discusses the general trends in the abundance of habitats and eels. Adickes (1888) discussed the wealth ('Überfluss') of young eels along the northern German coasts (where he lived), stating that these would gladly be given to the rest of the country, but within acceptable distances 'in the neighbourhood [of the coast], at about twelve hours distance ... we do not have any lack of eels'. 


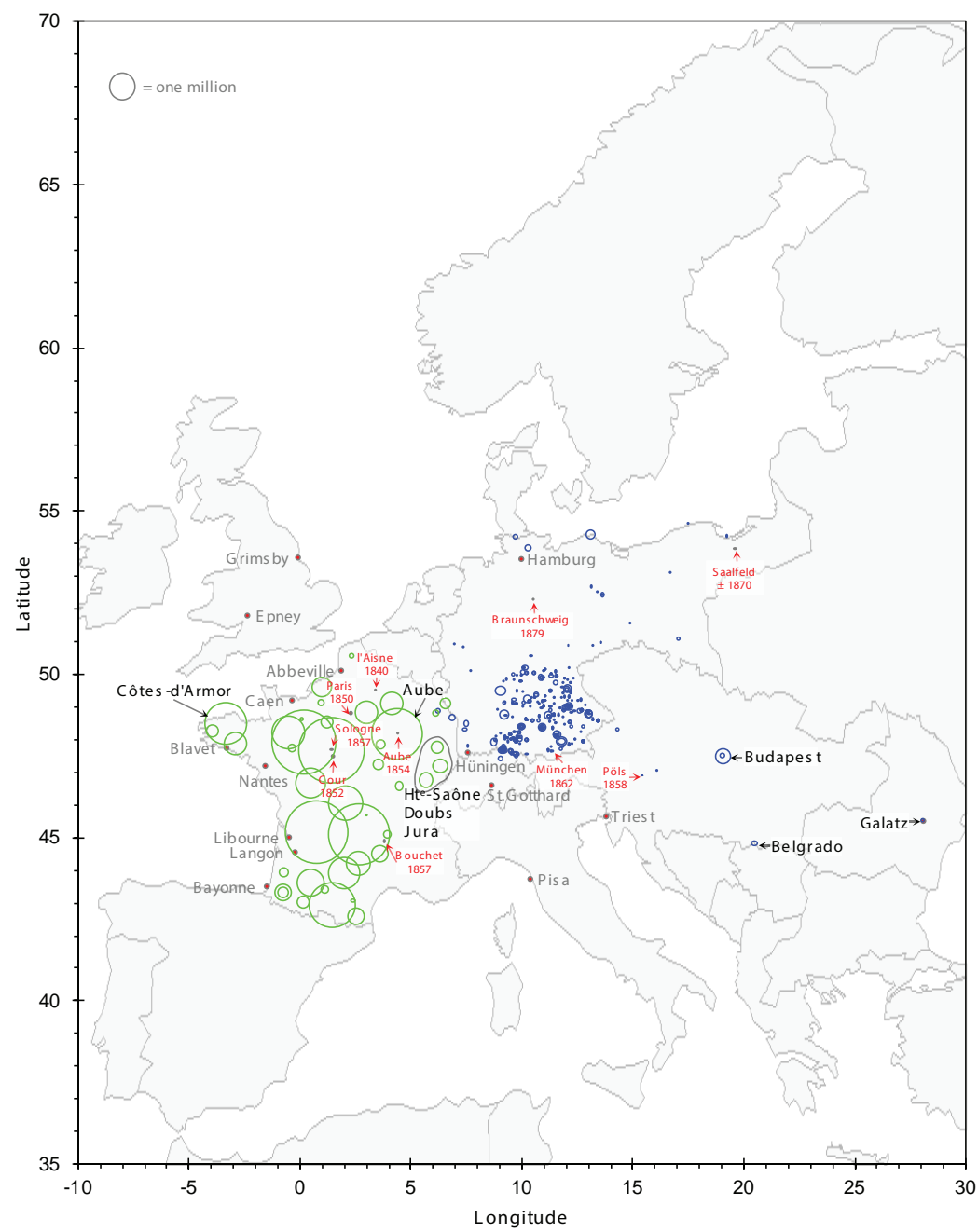

Figure 8. Spatial distribution of glass eel restocking between 1850 and 1900.

Red shows the location and year of early experiments. The number of glass eels involved is often very low in comparison to later restockings. Hence, the symbol size is not related to the number of eels in these early experiments.

Green shows total restocking over the 1850-1900 period in France, by département; the size of each symbol corresponds to the number of glass eel restocked in that département over the whole period.

Blue shows restocking by the Deutsche Fischerei Verein between 1850 and 1900; the size of each symbol corresponds to the number of glass eel in individual deliveries. Repeated stocking at the same location occurred only infrequently.

A few notable cases have been labelled in black; see text for further details. 
FAIRE MIEUX QUE LA NATURE?

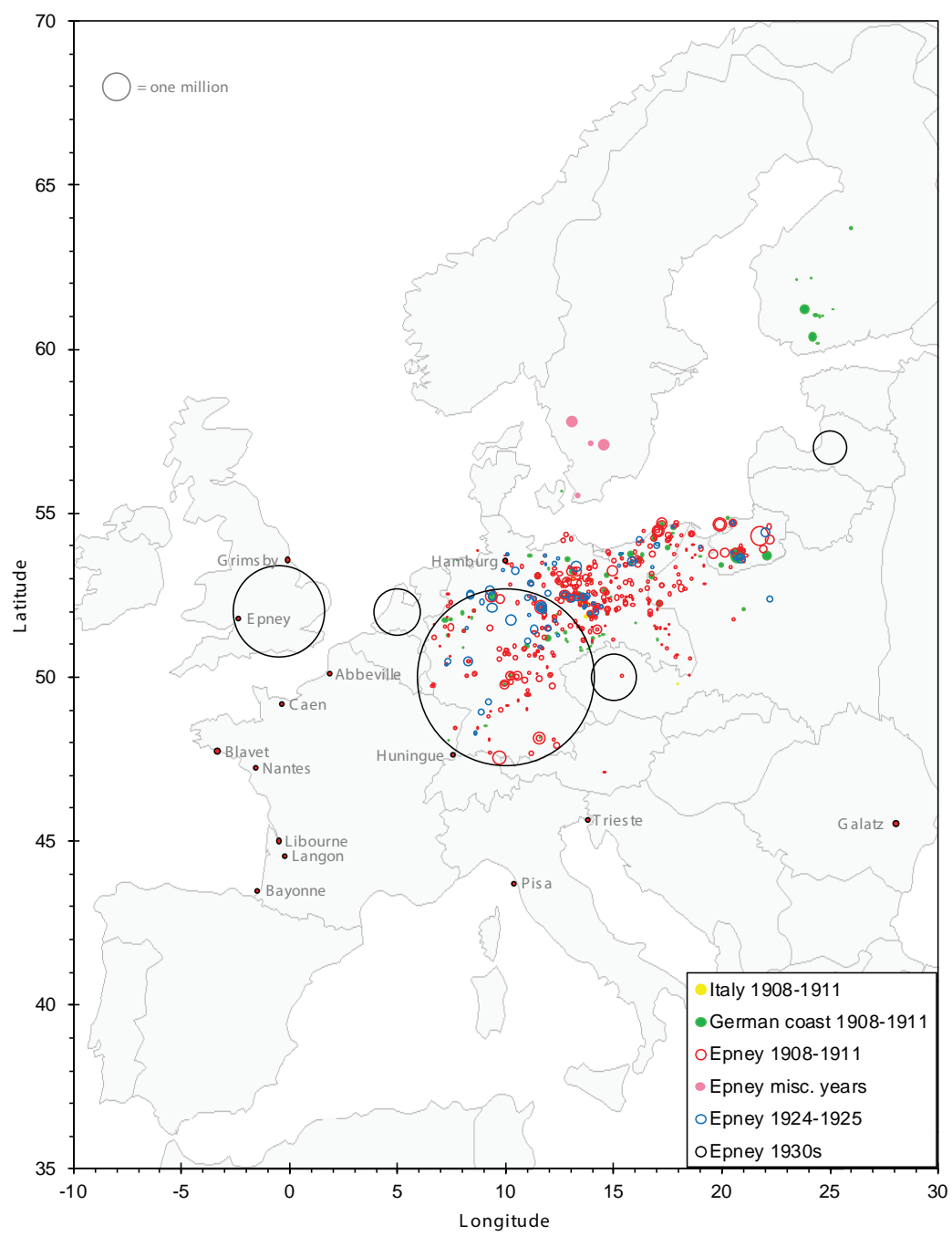

Figure 9. Spatial distribution of restocking between 1900 and 1940, by place of origin. For years up to 1930, the size of each symbol corresponds to the number of glass eel per delivery, for those years for which detailed information is available (and a few miscellaneous observations in Scandinavia in other years). For the 1930s, country totals over the whole decade are plotted. The maximum (Germany 1930s) corresponds to 44 million glass eel. 


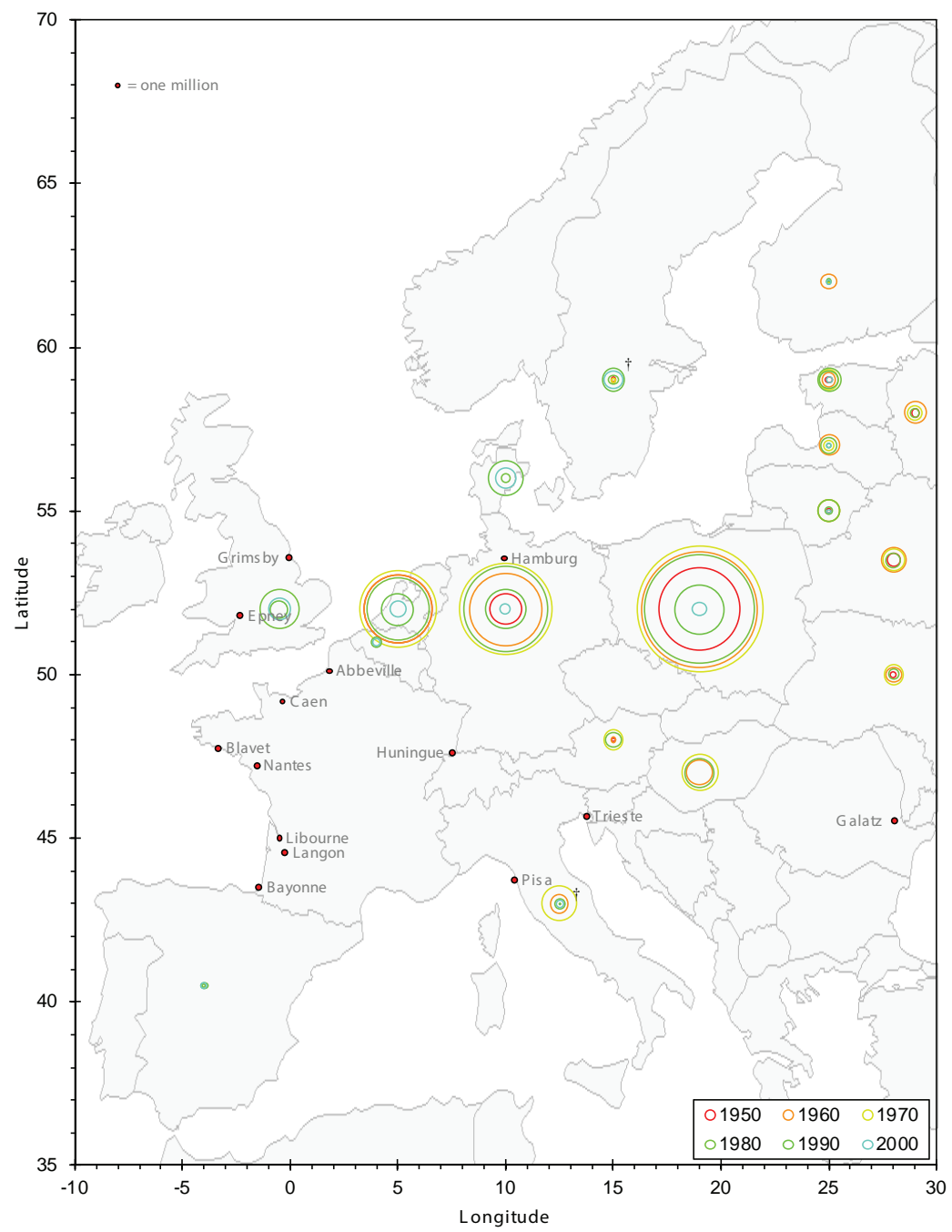

Figure 10. Spatial distribution of restocking, by country and decade, for the period from 1950 to 2010. The size of each symbol corresponds to the number of glass eel restocked over each whole decade. Note the difference in scaling between this and the other maps (symbol in the upper-left corner). The maximum (Poland, 1970s) corresponds to 558 million glass eel.

${ }^{\dagger}$ Symbols in this map represent numbers of glass eel, but ignore small numbers of bootlace eel being restocked. In Sweden (and less so in Estonia and Latvia), many more bootlace eel than glass eel have been restocked, especially in the 1970s. Since 1980, bootlace numbers imported from southern France into Italy surpassed the number of glass eel slightly. See text for details. 


\section{Restocking in times of war and peace}

Both wars and times of peace have influenced restocking programmes. The Franco-Prussian War (1870-1871) interrupted French salmon production in Huningue. For eel, this war stimulated rapid developments, in France as well as in Germany. In France, the loss of the salmon hatchery left few options for developing the national fisheries, primarily eel and shellfish. By 1879, a country-wide eel restocking programme was organised, which transported more glass eel than ever before. At the same time, the former French fish hatchery in Hüningen had come into German hands, giving the Germans greatly improved expertise and infrastructure for eel restocking, forming the basis for the effort to stock the River Danube. Though no self-reproducing stock was established in the Danube, the spatial scale of this programme and the extent of international cooperation were greater than ever. The Franco-Prussian War had positive effects on eel restocking on both sides of the conflict. The downside, however, was that piscicultural cooperation between the French and Germans ended, affecting other countries as well and having negative effects lasting from 1870 to 1965.

When World War One began, operation of the German glass eel station in Epney came to a complete standstill, only seven years after a promising start. In 1924, the Germans successfully restarted operations there, and international eel restocking cooperation was soon even stronger than before the War. World War One had halted the German restocking programme for nine years, but created no lasting division between the countries involved.

In contrast, World War Two had a tremendous impact on eel restocking. German glass eel imports came to an end until 1965; the Dutch immediately replaced the Germans in Epney, giving the Netherlands a head start after the war. The Polish, disadvantaged by the halt of German imports, solved that problem by a technical breakthrough that brought France back into the international restocking business and boosted post-War eel restocking to unprecedented levels. World War Two thus greatly disturbed German restocking programmes, but gave a boost to the Dutch, inspired the Polish to make a technical breakthrough and once again involved France in international glass eel transport.

Eel restocking programmes blossomed in times of peace. However, when intervals of peace had lasted for about twenty years, the restocking programmes often found themselves winding down and being discontinued, exemplified by the French programme of (1860)/1879-1890 or the German stocking of the River Danube of 1883-1897. German imports from Epney never experienced a lasting period of peace, both World Wars interrupting the programme. When peace finally returned in 1945, the Germans were banned from their own programme for twenty years, finally returning as a relatively minor player. For other participating countries, the success of post-War restocking was not due only to air transport, but also to the long period of political stability. 
The historical development of restocking has constituted a major technical challenge, impeded by the troubled, war-torn relationships between source and destination areas. Wars also led to the spread of expertise and forced people to develop new solutions.

Table 1. Summary of historical restockings, their predicted production, and observed total fishing yield for each episode discussed in the text. Informed guesses shown in italics. The reported fishing yield (of both wild and restocked eel) refers to Europe as a whole, including reconstructions for the non-reporting countries (see Dekker 2003b for details). For each episode, the year of maximum restocking is given, except for the period of decline, for which the minimum is given. The prices are inflation corrected (base year 2000); for the glass eel from Epney and for the period of decline, early and later prices are given; for the other episodes, we give a range. For comparison, the estimated total number of glass eel available on the market in France is shown (Briand et al. 2008, their Table 1, here converting tonnes into millions).

\begin{tabular}{|c|c|c|c|c|c|c|c|}
\hline Episode & $\begin{array}{l}\text { Total } \\
\text { restocking, } \\
\text { millions }\end{array}$ & $\begin{array}{l}\text { Peak } \\
\text { restocking } \\
\text { year }\end{array}$ & $\begin{array}{l}\text { Peak } \\
\text { restocking, } \\
\text { million/a }\end{array}$ & $\begin{array}{l}\text { Glass eel } \\
\text { catch (FR), } \\
\text { million/a }\end{array}$ & $\begin{array}{l}\text { Price for } \\
\text { end-users, } \\
€ / \mathrm{kg}\end{array}$ & $\begin{array}{l}\text { Expected } \\
\text { production, } \\
\text { tonnes } / a\end{array}$ & $\begin{array}{l}\text { Fishing } \\
\text { yield, } \\
\text { tonnes/a }\end{array}$ \\
\hline $\begin{array}{l}\text { Early } \\
\quad 1840-1880\end{array}$ & 17 & 1861 & 3.9 & ??? & $0-500$ & 130 & ??? \\
\hline $\begin{array}{l}\text { France } \\
\quad 1879-1890\end{array}$ & 32 & 1885 & 4.5 & ??? & $10-25$ & 150 & ??? \\
\hline $\begin{array}{l}\text { Danube } \\
\qquad 1881-1897\end{array}$ & 6 & 1889 & 0.7 & 600 & 155 & 23 & - \\
\hline $\begin{array}{l}\text { Epney } \\
\quad 1908-1940\end{array}$ & 174 & 1939 & 15.0 & 1000 & $180 \rightarrow 40$ & 500 & 20,000 \\
\hline $\begin{array}{l}\text { Heyday } \\
\quad 1945-1980\end{array}$ & 3368 & 1978 & 153.0 & 6000 & 40 & 5100 & 22,742 \\
\hline $\begin{array}{l}\text { Decline } \\
\quad 1980-2000\end{array}$ & 588 & 2009 & 2.5 & 600 & $40 \rightarrow 400$ & 83 & 8080 \\
\hline $\begin{array}{l}\text { Recovery } \\
\text { 2009-(ctd) }\end{array}$ & (ctd) & (ctd) & & 100 & $300-500$ & & 3287 \\
\hline
\end{tabular}

\section{For better or for worse}

We evaluate the effect of restocking on the net fishing yield, temporal trend, spatial distribution and expansion to new habitats; we also consider the potential effects of the escapement of restocked silver eel to the ocean.

From 1840 (de Rivière's first ideas) to 1952 (Dąbrowski's air transport), eel restocking had an extremely long period of technical development and scalingup. Over all the years before 1952, the total quantity used for restocking was about 225 million glass eel, in contrast to nearly 4,000 million thereafter. We estimate the restocking-based production of harvestable eel over the period of 
development at a few thousand tonnes. In the absence of historical catch records, it is difficult to compare this harvest with that of the naturally recruited stock. In the 1950s, the total production in Europe (natural and restocked combined) was over 20,000 tonnes per year (Figure 2), and it was probably in the same order of magnitude before World War Two as well. This makes it rather unlikely that restocking had contributed substantially to the total yield before the War. In the heyday of restocking after the War, we estimate that restocking produced some 5,000 tonnes per year, which is a significant part of the total yield (Figure 2). By the year 2000, restocking had declined to fewer than five million glass eel per year, producing not more than 200 tonnes per year - far below the total yield of 5,905 tonnes per year at that time. All in all, restocking has made a noticeable contribution to the fishing yield over a period of four decades since World War Two, but has not halted the decline of the stock and fishery in the same period.

During its heyday after 1950, most restocking took place in the Netherlands (18 per cent), Germany (21 per cent), and Poland (45 per cent), the other countries together accounting for only 15 per cent of the total. The contribution made by restocking varies considerably among countries. In the Netherlands, we estimate the peak production from restocking at several hundred tonnes, when total yield was still in the thousands of tonnes. In contrast, expected peak production from restocked eel reached approximately 2,000 tonnes per year in Poland, while the actual reported yield - combining natural and restocked eel - never reached that level. Further east, even small quantities of restocked glass eel made a welcome contribution to the very sparse natural stock. This apparently indicates that restocking has considerably expanded the spatial distribution of the stock and fisheries to the east, but the literature from the late 1800s suggests that restocking might have only compensated for the ongoing decline of the natural stock. ${ }^{44}$

In the 1880s, restocking in France was concentrated in the départements that did not adjoin the sea but were within reach of the railway from the Atlantic coast, roughly in the zone just west of the Massif Central (Figure 8).

44. For the Netherlands, Dekker (2004b) reported that the fishery on Lake IJsselmeer yielded approximately 4,000 tonnes per year, but Lake IJsselmeer has never been restocked. The historical fishing yield in the rest of the country (where restocking was practised) is scarcely documented, but was considered to be in the same order of magnitude.

With respect to the abundance of the stock, Benecke (1884) wrote: 'While it is simply not to be expected that the number of migrating elvers in rivers flowing into the Baltic should equal the number in the North Sea rivers, it is certainly justified to require that every owner of a water mill or other barrier build an eel ladder, because [eel] migration has also been observed at so many places in our provinces, even deep within the country'. The eel ladder Benecke described was constructed in Rendsburg (Schleswig), but Benecke himself had moved to Königsberg (eastern Prussia, now Russia); ‘our provinces' refers to the Königsberg area. His statement on migrating eel in eastern Prussia indicates that restocking in these areas may have compensated for newly built barriers, but probably did not substantially extend the natural distribution. Clearly, Benecke was not reporting from personal observation. 
The coastal départements provided glass eel to other départements, but did not restock themselves - apparently, natural recruitment in coastal areas did not require any supplementing. Restocking occurring west of the Massif Central, but not much farther east, constituted a moderate extension into areas of somewhat lower natural abundance, but definitely not into new habitats. Restocking in the River Danube was ineffective, and the numbers of glass eel used for that purpose were small (Figure 4), while restocking in northern Germany and Poland probably compensated for recent losses, but did not really exploit new habitats. Overall, the extent of new habitats opened up by restocking appears to be extremely limited. ${ }^{45}$

Recapitulating the above, we conclude that the prime objective - 'faire mieux que la nature' - has scarcely been accomplished. All that restocking has achieved is a moderate contribution to fishing yield, probably only partly compensating for ongoing decline, no change in the temporal trend or spatial distribution and no substantial extension into new habitats. Over time, objectives have been cut to the available cloth and, as a consequence, very few negative evaluations have ever been made. Restocking as such was successful and local yields increased in many places, but the overall restocking yield has generally been very low relative to the yield from natural recruits. Restocking was intended to do better than nature, but probably more often just partly compensated, during some periods, for worsening circumstances.

\section{Long-lasting hopes}

In the previous section, we pessimistically evaluated the net results of the eel restocking efforts. However, throughout the 175 years that restocking has now been practised, contemporary authors have almost consistently made positive statements and expressed hope. The negative evaluations in the late 1880s in France appeared in certain départements all over the country, but other départements kept up their hopes and continued their restocking at the same time. After the French national programme had come to an end (ca 1890), the few publications on regional restocking once more expressed positive expectations. Even in more recent times, restocking has been and is advocated as an important measure to mitigate the ongoing stock decline. In our view, the contrast between expectations and achievements might relate to a number of factors. ${ }^{46}$

45. The absence of restocking in coastal départements in France is paralleled by Adickes' (1888) observations in Germany. The exceptional restocking in Côtes-d'Armor, a coastal département, seeded the newly dug Canal de Nantes à Brest.

46. Positive views of restocking have been expressed by Millet (1870), Pouchet (1856), von Washington (1862), Haack (1882), Schmidt (1906), Fischer and Lübbert (1908), Dąbrowski (1952), Kokhenko (1969), Thurow (1979), Baer et al. (2011) and Wickström and Sjöberg (2013) - to name just a few optimists. Scientific advice has given mixed views (ICES-advice 1999, 2001). 
First, in almost all restocking programmes, little attention has been paid to post-evaluation. Anecdotal positive information or hearsay of success is considered adequate, and post-evaluation is frequently completely lacking. Only in very recent years, during the years of stock protection and recovery, has post-evaluation been taken seriously. ${ }^{47}$

Second, from 1840 to 1952, low survival during long transport was a limiting factor. A breakthrough concerning the transport problem - i.e. proven survival of glass eel during transport and after release - has been interpreted as a positive evaluation of restocking itself. Partial achievements have thus often been interpreted as proof of full success. ${ }^{48}$

Third, before 1870, the transport of live eel was mostly unsuccessful, but practices have since improved. Currently, there is no doubt that relocating young eel results in greater abundance, improved yield, and probably increased escapement of silver eel from the restocked area. This proof of principle is often interpreted as adequate evidence for the importance of restocking as a management measure. In the previous sections, we have demonstrated that the contribution from restocking has been moderate at best - the quantities restocked and consequently harvested are simply too small to make restocking that important. A proof of principle does not indicate importance in a quantitative sense.

Fourth, over the decades, restocking has been practiced in France, in southern Germany, northern Germany, other northern countries and eastern European countries. New countries and people have repeatedly made fresh starts, learning few, if any, lessons from others' experience.

Fifth, from 1840 to the present, restocking techniques have gradually developed. Every step forward effectively discredited past information for pre-evaluating future success - the new technique would enable positive results from that step onward. The latest step in this process is the current pregrowing of young eel in indoor tanks to avoid/reduce the natural mortality of the juveniles. Restocking advocates have generally always had high hopes of a golden future, and negative post-evaluations are merely unwelcome messages, ignored as much as possible. Often, technical improvements were an easy excuse for not evaluating past results.

Finally, most restocking programmes have been publicly funded, while the benefits were to accrue to local, small-scale, often minimally organised fishers. In modern times of stock protection, governments have often preferred restocking at public expense to restricting the yield/income of fishers and other stakeholders (e.g. the hydropower industry). Noting that, in restocking,

47. Anonymous (1891) discussed the catching of a single eel in the Black Sea, acknowledging that only the observation of young recruits will finally prove that reproduction is taking place. Anonymous (1889) described a basket full of eels in the market in Sulina and hearsay of montée being observed near Kilija. For a modern post-evaluation, see, for example, ICESWGEEL (2009).

48. von Washington (1862) and Haack (1882). 
earnings come a decade or more after the costs, governments have apparently not been very successful in either pre- or post-evaluating the effects of their actions on other people's income, many years later.

Over the 175 years that restocking has been practised, and all across Europe, eager planning and overambitious promises have been far more common than sound practice and clear-sighted evaluation. Even today's protection plans (Anonymous 2007; national Eel Management Plans) pay disproportionate attention to restocking, not because of its quantitative relevance, but in fidelity to past promises for the future.

\section{Fish or snake?}

Finally, we consider the importance of eel restocking for the development of aquaculture in general, and vice versa, and their embedding in history.

At the onset of the aquacultural revolution in France in the mid-1800s, scientists and authorities considered the eel a prominent candidate for further development. Its hardiness during transport in a stagecoach even made eel the fish of choice for the early experiments on translocating wild fish. In the years following, aquaculture developed rapidly, enabled by the discovery of artificial reproduction and the expansion of railway networks. Eel reproduction remaining a mystery, however, aquaculture soon focused on the successful salmonids, and left the unsuccessful eel behind. Technical progress in salmonid culture carried over to eel restocking (e.g. transport boxes with ice), but eel culture and restocking remained in the shadow of the aquacultural revolution. The modernisation of eel culture in the late 1900s once more exploited expertise developed for other fish species, but made no break-through on its own. That is, except for the very early period in the mid-1800s, eel restocking has had no relevance for the development of aquaculture in general. Noting its high price and appreciation, attempts to bring the eel level through artificial reproduction did (and do) continue since. But the eel is not a normal fish.

The effect of restocking on the dynamics of the eel population has been limited - spatially restricted, often not sustained and in most cases simply too little. Restocking has not markedly changed the overall trends and distribution patterns or halted the general decline of the stock and fishery. Nevertheless, restocking has been a dominant discussion topic in eel management, and still is in the current European protection and recovery policy on eel. Because of the differential distribution of the source and destination habitats, a straightforward technical redistribution problem was repeatedly influenced by political conflicts. At the same time, the abundance of the resource has not been a limiting factor, except for the last two decades. Restocking has been hindered by political conflicts, but restocking itself played no role whatsoever in any international conflict. 
An unsuccessful attempt to comprise the eel in the aquacultural revolution of the late 1800s; a temporally and spatially restricted effect of restocking on stock and yield; transports troubled by political conflicts - are we dealing with a minor issue, doomed to fail? Throughout the ages and all over Europe, the eel has attracted major attention from scientists, politicians, stakeholders and the public - and it still does. The eel is an iconic species on its own, a mythical animal, the object of regional culture and traditions - all over Europe. Restocking eel has been an intriguing option in its own right for scientists and politicians, endeavouring to support and restore the waning icon. Additionally, the eel stock being scattered all over Europe, international cooperation was a prerequisite for the enhancement of the fisheries in the past and still is for the protection of the stock now - bringing all the technical and political complexities that the restocking programmes have suffered from. Rather than being an important factor in history itself, restocking programmes have reflected the ongoing events all over Europe, more than any other fish stock has ever done. It is only within this historical context that we can understand the long-lasting hopes about restocking that poisoned, and still poison, international debates on fisheries development and stock protection, from the mid-1800s until today. ${ }^{49}$

By 2009, natural glass eel recruitment from the ocean had declined so far that restocking had almost come to an end. The total number transported by airplanes all across Europe in 2009 was lower than the 2.8 million transported by stagecoach from Nantes to Cour-Cheverny in 1852. Implementation of the European Eel Recovery Plan in 2009, however, radically averted that silent fade-out: now restocking was to be a management measure to recover the stock. Whether and, if so, how much restocking will indeed contribute to the recovery of the eel stock depends on the success of spawners of restocked origin, relative to that of their natural siblings. This requires the evaluation of processes operating in the distant Sargasso Sea, processes that no-one ever has observed. Results not being evaluable, the current high expectations of restocking as a stock recovery measure are effectively based on the faithful belief that one day, restocking will faire mieux que la nature.

49. Dekker (2000) analysed the contrast in scales between small-scale fisheries and the required continent-wide collaboration to protect and restore the stock; Dekker (2003c) discussed the complexity of eel management in comparison to other fish stocks; and Dekker (2008) discussed the iconic value of the eel and its exemplary role in resource protection programmes. Tsukamoto and Kuroki (2014) provide a romantic picture of the culture and traditions around eel throughout the world. 


\section{ACKNOWLEDGEMENTS}

The eel and its restocking are distributed all over Europe, and restocking has been practised for a long time. We could not have collected information over such a huge area, covering so many years, in so many languages, without the greatly appreciated help of so many colleagues and friends: Jean-Paul Binnert, Janis Birzaks, Uwe Braemick, Cedric Briand, Eleonora Ciccotti, Margo Dekker-Woltjer, Erik Fladung, Guy Fontenelle, Martin de Graaf, Bas de Groot, Reinhold Hanel, Cecile Huber, Don Jellyman, Dominique Juhe-Beaulaton, Jan Klein Breteler, Linas Ložys, Mariana Mesherjakova, Tomasz Nermer, Jaap Quack, Stanisław Robak, Tony Robinet, Eva Sers, Janek Simon, Audre Trumpiene, Håkan Wickström and Klaus Wysujack. We are much indebted to Stephen Sanborn (Proper English $\mathrm{AB}$ ) for furbishing our language, and to two anonymous reviewers and the editor for their critical remarks.

Part of this study was funded by the Swedish Agency for Marine and Water Management and by the French National Agency for Water and Aquatic Environments.

\section{REFERENCES}

Adickes, W. 1888. Oral presentation, cited by anonymous, in 'Zweiter Deutscher Fischereitag in Freiburg i. B.; Plenarversammlungen des Deutschen Fischereitag'. Allgemeine Fischerei-Zeitung 13(20): 241-242.

Androussow, N.I. 1897. La Mer Noire. Guide des excursions du VII Congres Géologique International. St. Petersburg : M. Stassuléwitsch.

Anonymous. 1852. Rapport de M. le Préfet sur le Pisciculture. Procès-Verbal des Délibérations du Conseil Général du Département de l’Isère. F. Allier, Grenoble. pp. 349-53.

Anonymous 1860. 'Instruction pratiques pour le repeuplement des cours d'eau'. Annales Forestières et Métallurgiques, Bureau des Annales Forestières, Paris. 19: 233-247.

Anonymous. 1864. 'Instruction pratiques pour le repeuplement des cours d'eau', in Anonymous, Code de la Pêche Fluviale. Paris: Imprimerie Impériale. pp. 55-77.

Anonymous. 1884. (no title) Circulare des Deutschen Fischerei-Verein im Jahre 1884. Berlin: W. Moeser Hofbuchdruckerei. p. 75.

Anonymous. 1887. 'Aufsteigen des Aals in Badischen Gewässern'. Circulare des Deutschen Fischerei-Verein im Jahre 1887. Berlin: W. Moeser Hofbuchdruckerei. pp. 52-3.

Anonymous. 1888a. 'An die rumänischen Fischer!' Circulare des Deutschen FischereiVerein im Jahre 1888. Berlin: W. Moeser Hofbuchdruckerei. pp. 94-5.

Anonymous. 1888b. 'Aalbrut'. Circulare des Deutschen Fischerei-Verein im Jahre 1888. Berlin: W. Moeser Hofbuchdruckerei. pp. 27-8.

Anonymous. 1889. 'Aal-Angelegenheiten'. Circulare des Deutschen Fischerei-Verein im Jahre 1889. Berlin: W. Moeser Hofbuchdruckerei. p. 32.

Anonymous. 1891. ‘Aale am Schwarzen Meer'. Circulare des Deutschen FischereiVerein im Jahre 1891. Berlin: W. Moeser Hofbuchdruckerei. p. 152. 
Anonymous. 2007. 'Council Regulation (EC) No 1100/2007 of 18 September 2007 establishing measures for the recovery of the stock of European eel'. Official Journal of the European Union L 248/17.

Ardizzone, G.D., S. Cataudella and R. Rossi. 1988. 'Management of coastal lagoon fisheries and aquaculture in Italy'. FAO Fisheries Technical Paper 293.

Baer, J., U. Brämick, M. Diekmann, H. Karl, C. Ubl and K. Wysujack. 2011. 'Fischereiliche Bewirtschaftung des Aals in Deutschland. Rahmenbedingungen, Status und Wege zur Nachhaltigkeit'. Schriftenreihe des Verbandes Deutscher Fischereiverwaltungsbeamter und Fischereiwissenschaftler e. V., Heft 16.

Benecke, B. 1880. Fische, Fischerei und Fischzucht in Ost- und Westpreussen. Königsberg: Hartungse Verlagsdruckerei.

Benecke, B. 1884. Die Wanderung der Aalbrut und die Einrichtung von Aalbrutleitern. Königsberg: Leupold.

Binnert, J.P. 1998. Historique de l'ancienne Pisciculture de Huningue. Pour mieux connaître la Petite Camargue Alsacienne. Michelbach-le-Bas: Verlag JPB.

Blanchère, H. de la 1877. 'L'aquiculture en France, en Europe et en Amérique’. Bulletin de Société Acclimatation (Paris) 3(4): 617-40.

Blanchère, H. de la 1880. La pêche en eau douce. Paris: Delarue.

Borne, M. von dem 1881. Die Fischzucht. Wiegandt: Paul Parey Verlag.

Bouchon-Brandely, G. 1875. Mémoire sur la pisciculture. Versailles: E. Aubert.

Briand, C., S. Bonhommeau, L. Beaulaton and G. Castelnaud. 2008. 'An appraisal of historical glass eel fisheries and markets: landings, trade routes and future prospect for management', in C. Moriarty (ed.), The Institute of Fisheries Management Annual Conference 2007. Westport: The Institute of Fisheries Management.

Ciccotti, E., F. Capoccioni and M. Schiavina. 2013. 'Report on the eel stock and fishery in Italy 2012/2013'. Annex to ICES-WGEEL 2013, pp. 513-48.

Coste, V. 1849. 'Recherches sur la domestication des poissons et sur l'organisation des piscines'. Comptes rendus de l'Académie des Sciences 29: 797-801.

Coste, V. 1850. 'Expériences sur les moyens de transport de la montée ou des jeunes anguilles'. Comptes rendus de l'Académie des Sciences 30: 473-75.

Coste, V. 1853a. Instructions Pratiques sur la pisciculture. Paris: V. Masson.

Coste, V. 1853b. Die neuesten und wichtigen Verbesserungen in der Fischzucht. Nach den Französischen bearbeitet. Quedlindburg und Leipzig: Druck und Verlag von Basse.

Coste, V. 1854a. 'Practical instructions in fish-raising', in W.H. Fry, A Complete Treatise on Artificial Fish-breeding. New York: Appleton and Co. pp. 29-110.

Coste, V. 1854b. Berättelse om Fiskskötsel. Stockholm: Johan Beckman.

Coste, V. 1855. Voyage d'exploration sur le littoral de la France et de l'Italie: Rapport à M. le ministre de l'agriculture, du commerce et des travaux publics, sur les industries de Comacchio, du lac Fusaro, de Marennes, et de l'Anse de l'Aiguillon. Paris: Imprimerie impériale.

Coumes, J. 1862. Notice historique sur l'établissement de pisciculture de Huningue. Strasbourg : Veuve Berger-Levrault. 


\section{WILLEM DEKKER AND LAURENT BEAULATON}

Dąbrowski, B. 1952. O zarybianiu wegorzem [The restocking of eel]. Gospodarra Rybna 4: 5-6.

Dannewitz, J., G.E. Maes, L. Johansson, H. Wickström, F.A.M. Volckaert and T. Järvi. 2005. 'Panmixia in the European eel: a matter of time...' Proceedings of the Royal Society B 272: 1129-1137. CrossRef

Dekker, W. 2000. 'The fractal geometry of the European eel stock'. ICES Journal of Marine Science 57: 109-21. CrossRef

Dekker, W. 2003a. 'On the distribution of the European eel and its fisheries'. Canadian Journal of Fisheries and Aquatic Sciences 60: 787-99. CrossRef

Dekker, W. 2003b. 'Did lack of spawners cause the collapse of the European eel, Anguilla anguilla?' Fisheries Management and Ecology 10: 365-76. CrossRef

Dekker, W. 2003c. 'Eels in crisis.’ ICES Newsletter 40: 10-11.

Dekker, W. 2004a. Slipping Through our Hands - Population Dynamics of the European Eel. Amsterdam: University of Amsterdam, Ph.D. thesis. http://www.diadfish.org/ doc/these_2004/dekker_thesis_eel.pdf

Dekker, W. 2004b. 'What caused the decline of Lake IJsselmeer eel stock since 1960?' ICES Journal of Marine Science 61: 394-404. CrossRef

Dekker, W. 2008. 'Coming to Grips with the Eel Stock Slip-Sliding Away', in M.G. Schlechter, N.J. Leonard and W.W. Taylor (eds), International Governance of Fisheries Eco-systems: Learning from the Past, Finding Solutions for the Future (Bethesda, Maryland: American Fisheries Society, Symposium 58), pp. 335-55.

Dekker, W. and L. Beaulaton. 2015. 'Climbing back up what slippery slope? Dynamics of the European eel stock and its management in historical perspective'. ICES Journal of Marine Science 73 (1): 5-14. CrossRef

Dubois, P. 1903. 'Les Poissons du département du Cher d'après la classification du Dr Moreau'. Bulletin de la Société centrale d'aquiculture et de pêche (1903): 53-9.

Duhamel de Monceau, H.L. 1769. Traité général des pesches et Histoire des poissons qu'elles fournissent, tant pour la subsistance des hommes que pour plusieurs autres usages qui ont rapport aux Arts et au Commerce. Paris: Saillant \& Nyon / Desaint.

Duparc, H.M. 1854. De kunstmatige vischteelt en vischfokkerij. Amsterdam: Gebr. Diederichs.

Eichelbaum, E. 1924. 'Das Auftreten der Aalbrut an der deutschen Küste und ihre erste Nahrungsaufnahme’. Wissenschaftlichen Meeresuntersuchungen (Helgoland) 15: $1-26$.

Elsner, B. 1899. 'Ueber die Besetzung der Binnengewässer mit Aalen'. Allgemeine Fischerei-Zeitung 24(7): 107-11.

FAO, 2014. FishStatJ, a tool for fishery statistics analysis, Release 2.11.4. Datasets: Capture Production 1950-2012 \& Fisheries Commodities Production and Trade 1976-2011. http://www.fao.org/fishery/statistics/software/fishstatj/en, accessed 1 Oct. 2014.

Fischer, F. and H. Lübbert. 1908. 'Die Organisation des Bezuges von Aalbrut aus England für deutsche Gewässer'. Zeitschrift für Fischerei 15: 17-60.

Gauckler, P.G. 1884. Instructions pratiques pour le repeuplement des cours d'eau. Instruction pour les gardes-pêche. Paris : Ministère des travaux publics. 
Ginneken, V. van, B. Muusze, J.K. Breteler, D. Jansma and G. van de Thillart. 2005. 'Microelectronic detection of activity level and magnetic orientation of yellow European eel, Anguilla anguilla L., in a pond'. Environmental Biology of Fishes 72: 313-20. CrossRef

Gobin, A. 1889. La pisciculture en eaux douces. Paris: Baillière et fils.

Godenier, C.-E.-P. 1852. De la Fécondation et de l'Eclosion Artificielle des Eufs de Poissons et de l'Education du Frai. Grenoble: Prudhomme.

Grassi, B. and S. Calandruccio. 1897. 'Fortpflanzung und Metamorphose des Aales'. Allgemeine Fischerei-Zeitung 22: 402-08, 423-32.

Haack, H. 1872. Die rationelle Fischzucht. Leipzig: Ed. Peter's Verlag.

Haack, H. 1877a. 'Offerte von Aalbrut'. Mittheilungen über Fischereiwesen 2(3): 22-3.

Haack, H. 1877b. 'Die Einführung von Aalen in das Donaugebiet'. Mittheilungen über Fischereiwesen 2(5): 33-5.

Haack, H. 1881. 'Bericht über die erste größere Aussetzung von Aalen in das Gebiet der Donau'. Circulare des Deutschen Fischerei-Verein im Jahre 1881. Berlin: W. Moeser Hofbuchdruckerei. pp. 123-25.

Haack, H. 1882. 'Aussetzung von 100000 jungen Aalen in das Donaugebiet'. Circulare des Deutschen Fischerei-Verein im Jahre 1882. Berlin: W. Moeser Hofbuchdruckerei. pp. 113-15.

Haack, H. 1883. 'Der Bezug von Aalbrut aus Italien und deren Ueberführung in das Donaugebiet‘. Circulare des Deutschen Fischerei-Verein im Jahre 1883. Berlin: W. Moeser Hofbuchdruckerei. pp. 51-60.

Haack, H. 1904. 'Die kaiserliche Fischzuchtanstalt bei Hüningen im Elsaß'. Allgemeine Fischerei-Zeitung 29(21): 401-05, 422-26, 442-46.

Higginbotham, J.A. 1997. Piscinae, Artificial Fish Ponds in Roman Italy. London: University of North Carolina Press..

Hofer, B. 1897. 'Welche Aussicht hat der Versuch zur Einbürgerung des Aales im Donaugebiet?' Allgemeine Fischerei-Zeitung 22(23): 445-49.

Hoffmann, R.C. 1995. 'Environmental change and the culture of common carp in medieval Europe'. Guelph Ichthyology Reviews 3: 57-85.

Hoffmann, R.C. 2005. 'A brief history of aquatic resource use in medieval Europe'. Helgoland Marine Research 59: 22-30. CrossRef

ICES-advice, 1999. 'Report of the ICES Advisory Committee on Fisheries Management, 1998'. International Council for the Exploration of the Sea, ICES cooperative research report $\mathrm{N}^{\circ} 229$ : 393-405.

ICES-advice, 2001. 'Report of the ICES Advisory Committee on Fishery Management, 2001'. International Council for the Exploration of the Sea, ICES cooperative research report $\mathrm{N}^{\circ} 246$ : 819-28.

ICES-WGEEL, 1997. 'Report of the Tenth Session of the Joint Working Group on Eels'. International Council for the Exploration of the Sea, ICES C.M. 1997/M:1.

ICES-WGEEL, 2009. 'Report of the 2009 Session of the Joint EIFAC/ICES Working Group on Eels (WGEEL), 7-12 September 2009, Göteborg, Sweden’. International Council for the Exploration of the Sea, ICES CM 2009/ACOM:15. 
ICES-WGEEL, 2011. 'Report of the 2011 session of the Joint EIFAAC/ICES Working Group on Eels. Lisbon, Portugal, from 5 to 9 September 2011'. EIFAAC Occasional Paper. No. 48; also known as: International Council for the Exploration of the Sea, ICES CM 2011/ACOM:18. Rome: FAO/Copenhagen: ICES.

ICES-WGEEL, 2012. 'Report of the Joint EIFAAC/ICES Working Group on Eels (WGEEL), 3-9 September 2012, Copenhagen, Denmark'. International Council for the Exploration of the Sea, ICES CM 2012/ACOM:18.

ICES-WGEEL, 2013. 'Report of the Joint EIFAAC/ICES Working Group on Eels (WGEEL), 18-22 March 2013 in Sukarietta, Spain, 4-10 September 2013 in Copenhagen, Denmark'. International Council for the Exploration of the Sea, ICES CM 2013/ACOM:18.

ICES-WGEEL, 2015. 'Report of the Joint EIFAAC/ICES/GFCM Working Group on Eel (WGEEL), 24 November-2 December 2015, Antalya, Turkey’. International Council for the Exploration of the Sea, ICES CM 2015/ACOM:18..

ICES-WKEPEMP, 2013. 'Report of the Workshop on Evaluation Progress Eel Management Plans (WKEPEMP), 13-15 May 2013, Copenhagen, Denmark'. International Council for the Exploration of the Sea, ICES CM 2013/ACOM:32.

Kinsey, D. 2006. 'Seeding the water as the earth: The epicenter and peripheries of a western aquaculture revolution'. Environmental History 11: 527-66. CrossRef

Kokhenko, V. 1969. Европейский Угорь [Evropeiskii ugor, European eel]. Moscow: Пищевая промышленность [Pishchevaya promyshlennost, Food Industry].

Kreitmann, L. 1938. 'L'état actuel du saumon en France'. Bulletin de la Société Nationale d'Acclimatation 9-10: 1-20.

Larbalétrier, A. 1886. Traité-manuel de pisciculture d'eau douce. Bibliothèque des professions, Série H, No 20. Paris: J. Hetzel et $C^{\text {ie }}$.

Le Clerc, J. 1930. 'L'anguille dans le bassin de la Loire'. Bulletin Français de Pisciculture 2(19) : 145-52, 177-82.

Lübbert, H. 1907. 'Neue Forschungsergebnisse über das Leben des Aals und deren Einfluß auf die Aalfischerei'. Verhandlungen des Naturwissenschaftlichen Vereins in Hamburg, dritte Folge XV. Hamburg: L. Friederichsen \& Co, pp. XLIX-LII.

Lübbert, H. 1910. 'Die Besetzung deutscher Gewässer mit Aalbrut im Jahr 1909'. Zeitschrift für Fischerei 15: 182-233.

Lübbert, H. 1925a. 'Die Wiederaufnahme der Einfuhr von Aalbrut aus dem Severn (West-England) nach Deutschland'. Allgemeine Fischerei-Zeitung 50(3): 35-9.

Lübbert, H. 1925b. 'Die Einfuhr von Aalbrut aus dem Severn (West-England) nach Deutschland im Jahre 1925’. Allgemeine Fischerei-Zeitung 50(12): 203-09.

Lübbert, H. and F. Fischer.1911. 'Bezetzung deutscher Gewasser mit Aalbrut im Jahre 1910’. Zeitschrift für Fischerei 15(4): 251-318.

Marsilius, A.F. 1726. Danubius pannonico-mysicus, observationibus geographicis, astronomicis, hydrographicis, historicis, physicis perlustratus et in sex Tomos digestus. Tomus IV. De piscibus in aquis Danubii viventibus. Hagae et Amstelodami: P. Gosse, R. Chr. Alberts, P. de Hondt, Herm. Uytwerf \& Franç. Changuion.

Meyer, J. 1878. 'Ein Gang durch die Kaiserliche Fischzucht-Anstalt bei Hüningen'. Volksblatt, Eine Wochenzeitschrift mit Bildern. Straßburg im Elsaß: VolksblattVerlag. 29: 227-29, 234-38, 396-97. 


\section{FAIRE MIEUX QUE LA NATURE?}

Meyer, P.F. 1951. 'Die Aalbrutfangstation von Herbrum in Oldenburg'. Fischwirt 1: 207-12.

Millet, C. 1870. La culture de l'eau. Tours: Alfred Mame et Fils éditeurs.

Millet, C. 1878 (oral presentation) Bulletin Mensuel de la Société d'Acclimatation $3^{\mathrm{e}}$ serie, tome V, No 1, p. 271

Milne-Edwards, H. 1850. 'Rapport sur l'Empoissonnement des Rivières'. Moniteur Universel. Paris: Panckoucke.

Noël, E. 1856. Pisciculture, Pisciculteurs et Poissons. Paris: F. Chamerot.

Nordqvist, H. 1928. 'Försök rörande import och inplantering i svenska sjöar av engelsk glasål’. Skrifter utgivna av Södra Sveriges Fiskeriförening. Lund: Carl Bloms Boktryckeri. 1: 60-86.

Okamura, A., N. Horie, N. Mikawa, Y. Yamada and K. Tsukamoto. 2014. 'Recent advances in artifical production of glass eels for conservation of anguillid eel populations'. Ecology of Freshwater Fish 23: 95-110. CrossRef

Peck, A.L. 1970. Aristotle, Historia Animalium. London: William Heinemann Ltd.

Pouchet, F-A. 1856. Lettre sur les bancs d'anguilles de la Seine et sur l'industrie de Commachio. Rouen: A. Péron.

Raveret-Wattel, M.C. 1883. 'Rapport sur la Situation de la Pisciculture à l'Étranger, d'après les documents recueillis à l'Exposition internationale de produits et engins de pêche de Berlin en 1880'. Bulletin de Société Nationale d'Acclimatation de France (Paris) 3(10) : 508-51.

Ringuet, S., F. Muto and C. Raymakers. 2002. 'Eels: Their Harvest and Trade in Europe and Asia'. Traffic Bulletin 19(2): 2-27.

Rivière, L.R. baron de. 1841. 'Considérations sur les poissons, et particulièrement sur les Anguilles'. Mémoires d'Agriculture, d'Economie Rurale et Domestique. Paris : Société Royale et Centrale d'Agriculture.1840: 171-199d.

Röhler, E. 1933. 'Die Ergebnisse der Fischerei auf Aal in Deutschland'. Fischerei Zeitung 36(45): 541-43, 555-58, 567-69.

Röhler, E. 1939. 'Bericht über die Aalbrutgewinnung im Frühjahr 1939'. FischereiZeitung 42(26): 305.

Rossi, R. and S. Cataudella. 1998. 'La produzione ittica nelle Valli di Comacchio'. Laguna 5: 67-76.

Schmidt, J. 1906. 'Contributions to the life-history of the eel (Anguilla vulgaris, Flem.)'. Rapports et procès-verbaux des réunions du Conseil permanent international pour l'exploration de la mer 5: 137-264.

Schmidt, J. 1922. 'The Breeding Places of the Eel'. Philosophical Transactions Royal Society, series B. 211:178-208.

Soubeiran, M.L. 1865. 'Note on the cultivation of eels'. Annals and Magazine of Natural History 16(3): 384.

Tesch, F.-W. 1973. Der Aal. Hamburg: P.Parey.

Tesch, F.-W. 2003. The Eel. Oxford: Blackwell Science. CrossRef

Thurow, F. (ed.) 1979. 'Eel Research and Management'. Rapports et Procès-Verbaux des Réunions du Conseil International pour l'Exploration de la Mer 174.

Tsukamoto, K. and M. Kuroki. 2014. Eels and Humans. Tokyo: Springer. CrossRef 


\section{WILLEM DEKKER AND LAURENT BEAULATON}

Tucker, D.W. 1959. 'A new solution to the Atlantic eel problem'. Nature 183: 495-501. CrossRef

Vibraye, G.M.P.L. Hurault marquis de. 1854. 'Observations sur la Pisciculture'. Bulletin mensuel de la Société Zoologique d'Acclimatation. Paris, Goin, libraire de la Société Zoologique d'Acclimatation 1: 331-39.

Vivier, P. 1956. 'Un important centenaire: Rémy-Géhin, Haxo, Coste et l'établissement d’Huningue (1843, 1853-1953)'. Bulletin Français de Pisciculture 181: 121-38. CrossRef

Washington, M.E. Baron von. 1862. 'Beiträge zur Fischzucht'. Wochen-Blatt der Kaiserlich-Königlichen Steiermärkischen Landwirthschafts-Gesellschaft 11(11): 81-2; 11(12): 89-90.

Westin, L. 1998. 'The spawning migration of European silver eel (Anguilla anguilla L.) with particular reference to stocked eel in the Baltic'. Fisheries Research 38(3): 257-70. CrossRef

Wickström, H. and Sjöberg, N.B. 2013. 'Traceability of stocked eels - the Swedish approach'. Ecology of Freshwater Fish 23(1): 33-9. CrossRef 